\title{
Modified Glassy Carbon Electrode with Polypyrrole Nanocomposite for the Simultaneous Determination of Ascorbic acid, Dopamine, Uric acid, and Folic Acid
}

\author{
Khadijeh Ghanbari* and Sepideh Bonyadi \\ Department of Chemistry, Faculty of physics and chemistry, School of Science, Alzahra University, Vanak, Tehran \\ 1993891167, Iran
}

\begin{abstract}
A fast and simple method for synthesis of $\mathrm{Cu}_{\mathrm{x}} \mathrm{O}-\mathrm{ZnO} / \mathrm{PPy} / \mathrm{RGO}$ nanocomposite by electrochemical manner have been reported in this paper. For testing the utility of this nanocomposite we modified a GCE with the nanocomposite to yield a sensor for simultaneous determination of four analytes namely ascorbic acid (AA), dopamine (DA), uric acid (UA), and folic acid (FA). Cyclic voltammetry (CV) and Differential pulse voltammetry (DPV) selected for the study. The modified electrode cause to enhance electron transfer rate so overcome to overlapping their peaks and consequently having the ability to the simultaneous determination of AA, DA, UA, and FA. To synthesis confirmation of the nanocomposite, Field emission scanning electron microscopy (FE-SEM), Raman spectroscopy, and electrochemical impedance spectroscopy (EIS) were applied. The linearity ranges were $0.07-485 \mu \mathrm{M}, 0.05-430 \mu \mathrm{M}, 0.02-250 \mu \mathrm{M}$ and $0.022-180 \mu \mathrm{M}$ for AA, DA, UA, and FA respectively and the detection limits were $22 \mathrm{nM}, 10 \mathrm{nM}, 5 \mathrm{nM}$ and $6 \mathrm{nM}$ for AA, DA, UA, and FA respectively Also, the obtained electrode can be used for the determination of the AA, DA, UA, and FA in human blood, and human urine real samples.
\end{abstract}

Keywords : Electrochemical Sensor, Reduced Graphene Oxide, Ascorbic Acid, Dopamine, Uric Acid, Folic Acid

Received : 31 July 2019, Accepted : 9 September 2019

\section{Introduction}

One of the essential vitamins in the human diet is ascorbic acid (AA) and that is present in the mammalian brain along with various neurotransmitter amines [1]. Its utilization is in drinks and foods as an antioxidant to prevent and treatment of mental illness, common cold, infertility, cancer, and AIDS [2]. Dopamine (DA) is a prominent neurotransmitter, which its responsibility is in the function of the central nervous, renal, hormonal and cardiovascular system [3-5]. Several serious neurological diseases such as Parkinson's and schizophrenia are due to DA deficiency in the human body [6]. Another analyte that is the primary final purine metabolism product in the

*E-mail address: kh.ghanbari@alzahra.ac.ir (kh_ghanb@yahoo.com) DOI: https://doi.org/10.33961/jecst.2019.00472

This is an open-access article distributed under the terms of the Creative Commons Attribution Non-Commercial License (http://creativecommons.org/licenses/by-nc/4.0) Attribution Non-Commercial License (http://creativecommons.org/licenses/by-nc/4.0)
which permits unrestricted non-commercial use, distribution, and reproduction in any which permits unrestricted non-commercial use, distrib
medium, provided the original work is properly cited. human body is Uric acid (UA). The abnormal amount of UA causes some of the diseases, such as Lesch-Nyhan syndrome and hyperuricemia, and gout [7]. A water-soluble vitamin folic acid (FA, N-[p$\{[(2$-amino-4- hydroxy-6-pteridinyl) methyl] amino $\}$ benzoyl]-l-glutamic acid, Vitamin M) is synthesized in nature by plants (green leaves, algae) and microorganisms (yeast, bacteria). FA determination in the food, pharmaceutical, and clinical samples has received much attention because newborns neural tube defects and diseases like megaloblastic anemia, cancer, Alzheimer's are due to fail of that. FA participates in the synthesis of nucleotide, cell division, gene expression, and gene expression with vitamin B12 [8,9]. The AA, DA, UA, and FA levels have intercommunication with the human physiological function. Deficiency or maladjustment in their levels may lead to many diseases. Therefore, simultaneous determination of AA, DA, UA, and FA has great importance in diagnoses, and controlling mentioned diseases. 
A range of analytical techniques such as chromatography [10], spectrophotometry [11], chemiluminescence [12], capillary electrophoresis [13], FTIR and Raman spectrometry [14] and flow injection analysis using various methods of detection $[15,16]$ are reported in the literature for detection of these biological molecules. All these methods have disadvantages, for example long analysis times, high costs, the requirement for sample pretreatment and compressing system, temperature control systems, separation systems and other spectrophotometric or electric detection systems and in some cases low sensitivity and selectivity $[17,18]$. In comparison, the advantages of electrochemical methods are low cost, high sensitivity and short measurement time. However, one major problem is that the oxidation peaks of these electro active species are too close at an unmodified electrode, which results in overlapping voltammetric response and making their simultaneous detection highly difficult [19]. To overcome this problem, it is necessary to modifying the electrode. In most cases, this modification increases the sensitivity, selectivity and reproducibility compared to conventional electrodes. A number of modified electrodes have been utilized for the simultaneous detection of these molecules such as Ni NPs@Poly1,5DAN/GCE [20], Ag-PPy/GCE [21], and AuNCs/ AGR/MWCNT/GCE [22].

Numerous of this nanomaterials modified electrodes are ideal candidates to tackle the challenge of bioanalytical problems owing to their unique mechanical, physical and chemical properties.

A kind of crucial carbon material, namely graphene with a flat monolayer of carbon atoms in a hexagonal lattice had attracted innumerable attention since it was first reported in 2004 [23]. One of the graphene usages is the sensitive determination of various drugs molecules, due to their excellent conductivity because of $\pi-\pi$ stacking and synergetic effects with other materials [24,25].

Polypyrrole (PPy) is one of the most important conducting polymers and can be considered as a promising material with several characteristics, such as relative good conductivity, easy synthesis, large surface area, and low cost. Studies have also been conducted on the biosensor applications of PPy [26].

It should mention that, for nanofilling of polymer matrices, graphene sheets can be used and so high electrical conductivity, excellent mechanical strength, high chemical stability, and high surface area achieved [27].

Transition metals like copper, zinc, nickel, silver and cobalt and their oxides have been used in the sensors, solar cells, catalysis, and the photocatalyst. Two of them are Zinc oxide ( $\mathrm{ZnO}$ ), (an n-type metal oxide semiconductor, $3.37 \mathrm{eV}$ band gap), and Copper oxide $(\mathrm{CuO})$ (a p-type semiconductor, $1.2 \mathrm{eV}$ band gap) [28,29].

Actually, the concept of using p- and n-type semiconductors as well as their mixtures to improve sensor performance has been reported [30-32]. It has been suggested that alloying $\mathrm{Cu}_{\mathrm{x}} \mathrm{O}$ into $\mathrm{ZnO}$ can help form the $p-n$ junction that leads to electron transfer became easier [33]. Metal nanoparticles (MNPs) can be incorporated into conductive polymers that cause to improve electrocatalytic properties and system conductivities [34,35].

In this article, fast and simple preparation of a glassy carbon electrode modified with $\mathrm{Cu}_{\mathrm{x}} \mathrm{O}-\mathrm{ZnO}$ / $\mathrm{PPy} / \mathrm{RGO}$ nanocomposites was reported and the electrocatalytic oxidations of AA, DA, UA, and FA were studied. Amazing results were achieved for simultaneous electrocatalytic detection of AA, DA, UA, and FA within a long linear range and low detection limit.

\section{Experimental}

\subsection{Chemicals and instrumentation}

AA, DA, UA, and FA were purchased from SigmaAldrich. Pyrrole, acetic acid, zinc nitrate, copper nitrate, and sodium hydroxide were obtained from Merck. All other chemicals were of analytical grade and used as received. Pyrrole was distilled under vacuum and stored froze. Phosphate buffer solution (PBS, 0.1 M, pH 7.0) was employed as a supporting electrolyte. All the solution prepared by double distilled water.

The surface morphological characterization of $\mathrm{Cu}_{\mathrm{x}} \mathrm{O}-\mathrm{ZnO} / \mathrm{PPy} / \mathrm{RGO} / \mathrm{GCE}$ was examined by means of field emission scanning electron microscopy (FESEM) (MIRA3, TESCANZ, Czech Republic) at an accelerating voltage of $20 \mathrm{kV}$, Raman spectra were recorded on a Thermo Nicolet Dispersive Raman Spectrometer, with a $532 \mathrm{~nm}$ Laser beam at $30 \mathrm{~mW}$ and a charge coupled device detector with a $4 \mathrm{~cm}^{-1}$ resolution. The spectra were accumulated three times for $30 \mathrm{~s}$ each. Electrochemical impedance spectroscopy (EIS) was performed by Zahnner PP201, Ger- 


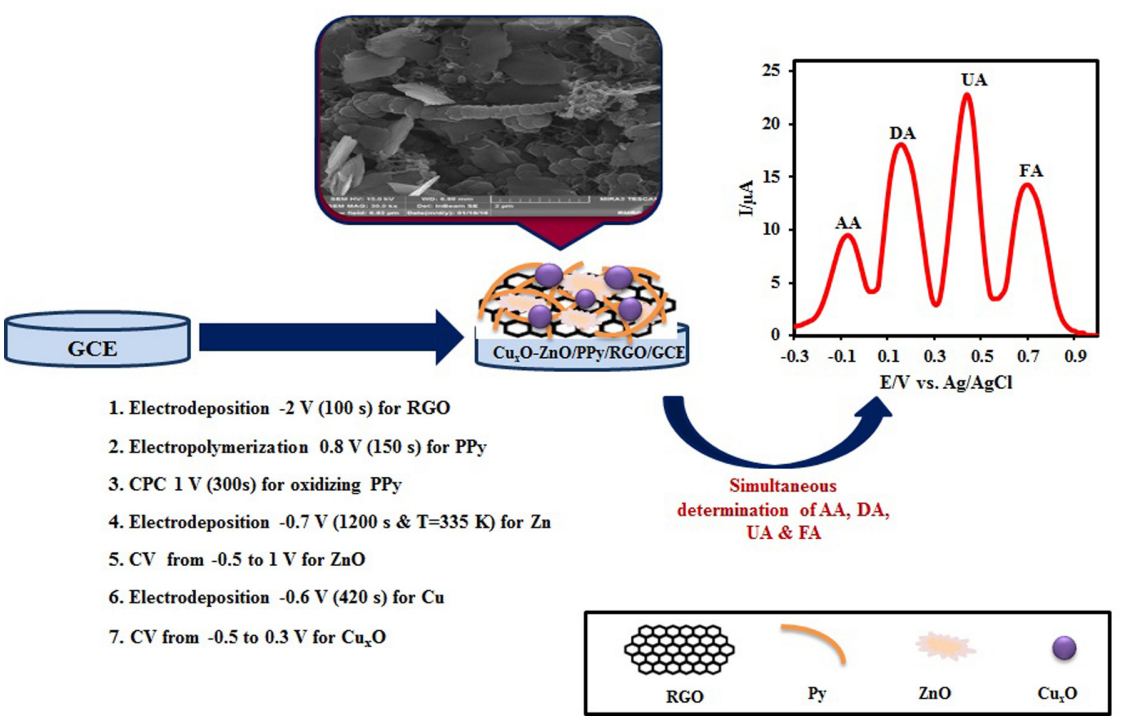

Scheme 1. Schematic illustration of stepwise electrode modification.

many that was a 4-quadrant power potentiostat designed to apply and sink high currents up to $\pm 20 \mathrm{~A}$ at a voltage range of $\pm 10 \mathrm{~V}$. The total power dissipation of the PP201 was 200W. An electrochemical system analyzer (Sama Instruments, Iran) performed electrochemical measurements. A conventional three-electrode system was used, containing an $\mathrm{Ag}$ / $\mathrm{AgCl} /$ saturated $\mathrm{KCl}$ as a reference electrode, a $\mathrm{Pt}$ wire as a counter electrode, and a bare or modified glassy carbon electrode (GCE) as working electrode.

\subsection{Preparation of the modified electrodes}

The preconditioning of a bare GCE was done in this way, polishing successively with $0.05 \mu \mathrm{m}$ alumina slurry on a synthetic cloth, rinsed with pure water, and sonicated subsequently in a 1:1 double distilled water and ethanol for $5 \mathrm{~min}$. Graphene oxide (GO) was synthesized directly from graphite by Hummers method $[36,37]$. In this paper, $\mathrm{Cu}_{\mathrm{x}} \mathrm{O}-\mathrm{ZnO} /$ PPy/RGO nanocomposites were synthesized according to our previous works [26]. The procedure was briefly described as follows: The GO was deposited and reduced simultaneously on the GCE by applying a constant potential of $-2.0 \mathrm{~V}$ vs. $\mathrm{Ag} / \mathrm{AgCl}$ for $100 \mathrm{~s}$. After that, PPy nanofibers were electrosynthesized on RGO/GCE potentiostatically by applying a constant potential $0.8 \mathrm{~V}$ vs. $\mathrm{Ag} / \mathrm{AgCl}$ for $150 \mathrm{~s}$. Then, electrodeposition of $\mathrm{ZnO}$ nanosheets was carried out potentiostatically $=(-0.7 \mathrm{~V}$ for $20 \mathrm{~min})$. Finally, the
$\mathrm{Cu}_{\mathrm{x}} \mathrm{O}$ nanoparticles were electrochemically deposited on the $\mathrm{ZnO} / \mathrm{PPy} / \mathrm{RGO} / \mathrm{GCE}$ surface by applying a constant potential of $-0.6 \mathrm{~V}$ for $420 \mathrm{~s}$. All of these procedures are depicted pictorially in scheme 1 .

\subsection{Method validation and optimization}

All experimental parameters that may affect determination process including buffer $\mathrm{pH}$, scan rate, electrodeposition time of $\mathrm{RGO}, \mathrm{ZnO}, \mathrm{CuO}$, and electrosynthesis time of PPy were optimized for sensor preparation to obtain the best potential peaks separation and highest currents of all four species. The results are shown in the supplementary information (Figures S1-S4). The method was validated according to ICH guidelines [38] including linearity, specificity, accuracy and precision.

\section{Results and Discussion}

3.1 Characterization of the $\mathrm{Cu}_{\mathrm{x}} \mathrm{O}-\mathrm{ZnO} / \mathrm{PPy} / \mathrm{RGO} / \mathrm{GCE}$

Fig. 1 shows a comparison of the morphology of RGO/GCE, PPy/GCE, ZnO/RGO/GCE, ZnO/PPy/ $\mathrm{RGO} / \mathrm{GCE}, \mathrm{Cu}_{\mathrm{x}} \mathrm{O} / \mathrm{RGO} / \mathrm{GCE} \mathrm{Cu}_{\mathrm{x}} \mathrm{O} / \mathrm{PPy} / \mathrm{RGO} / \mathrm{GCE}$, and $\mathrm{Cu}_{\mathrm{x}} \mathrm{O}-\mathrm{ZnO} / \mathrm{PPy} / \mathrm{RGO} / \mathrm{GCE}$ by FE-SEM. As you see in Fig. 1a RGO sheets possess many wrinkles on their surfaces and edges, which provide them with large specific surface area. In Fig. 1b PPy nanofibers film have a very large surface to volume ratio due to a well-ordered polymer chain structure, which is use- 

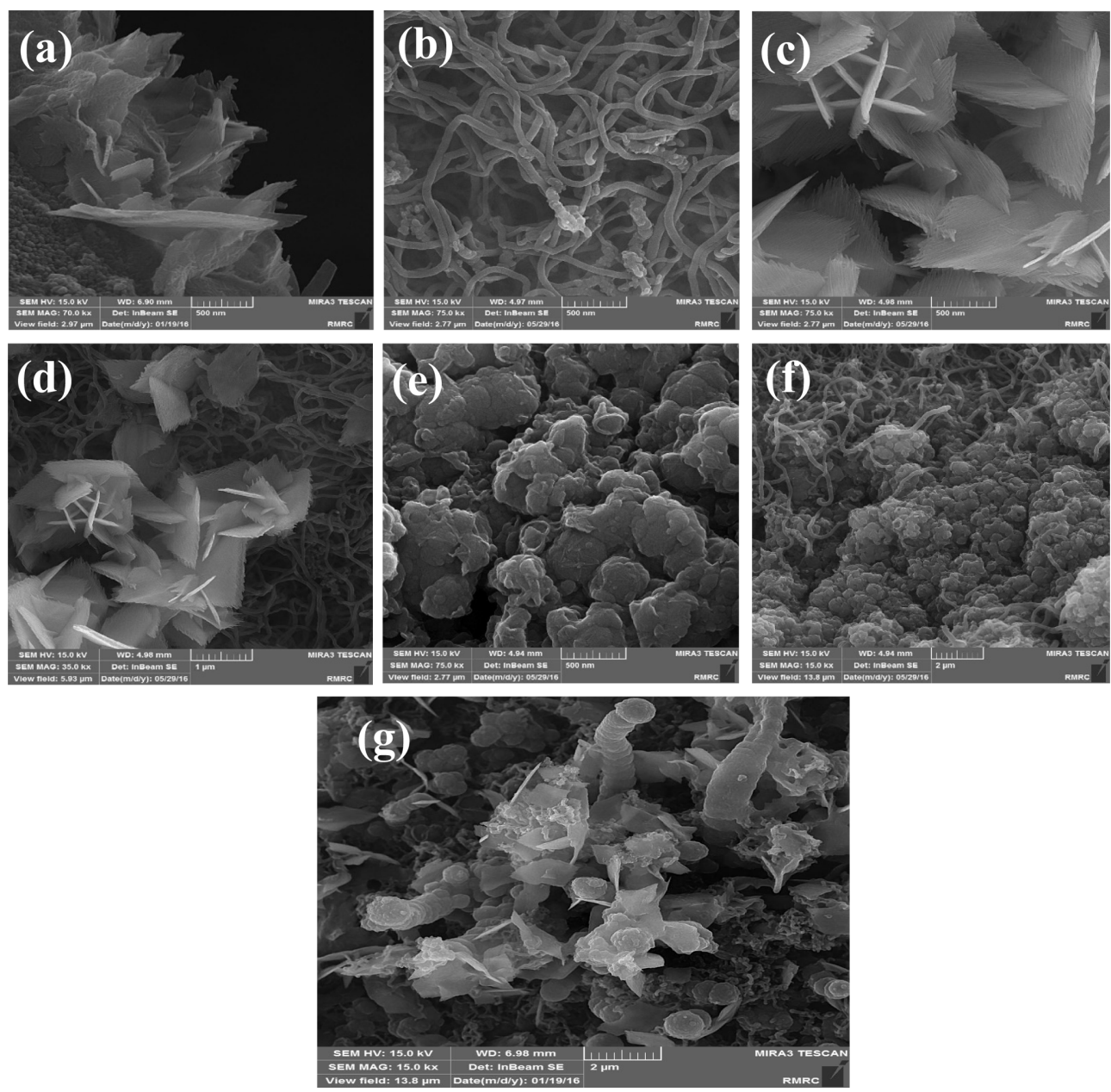

Fig. 1. FE-SEM pictures of (a) RGO, (b) PPy, (c) $\mathrm{ZnO} / \mathrm{RGO}$, (d)ZnO/PPy/RGO, (e). $\mathrm{Cu}_{\mathrm{x}} \mathrm{O} / \mathrm{RGO}$, (f). $\mathrm{Cu}_{\mathrm{x}} \mathrm{O} / \mathrm{PPy} / \mathrm{RGO}$ and (g) $\mathrm{CuxO}-\mathrm{ZnO} / \mathrm{PPy} / \mathrm{RGO}$.

ful for the incorporation of nanoparticles and transport of electrical carriers along one controllable direction. Fig. $1 \mathrm{c}$ and $\mathrm{d}$ show $\mathrm{ZnO} / \mathrm{RGO} / \mathrm{GCE}$ and $\mathrm{ZnO} / \mathrm{PPy} / \mathrm{RGO} / \mathrm{GCE}$, respectively. As you see, the $\mathrm{ZnO}$ have nanosheets shape with a very low thickness of a few nanometers. Fig. 1e and $\mathrm{f}$ show $\mathrm{Cu}_{\mathrm{x}} \mathrm{O} /$ $\mathrm{RGO} / \mathrm{GCE}$ and $\mathrm{Cu}_{\mathrm{x}} \mathrm{O} / \mathrm{PPy} / \mathrm{RGO} / \mathrm{GCE}$, respectively. In these pictures, you see $\mathrm{Cu}_{\mathrm{x}} \mathrm{O}$ nanoparticles with globular shapes and small sizes. Finally, in Fig. 1g, showed spherical flower-like microsphere morphology, with the globular 3D structure of the $\mathrm{Cu}_{\mathrm{x}} \mathrm{O}$ and nanostructures of $\mathrm{ZnO}$. As you see, the $\mathrm{ZnO}$ nanosheets and $\mathrm{Cu}_{\mathrm{x}} \mathrm{O}$ nanoparticles evenly distributed on the polypyrrole nanofibers and graphene sheets.
One of the most widely used techniques to characterize the structural and electronic properties of carbon materials is Raman spectroscopy. As shown in Fig. 2a, it is clear that $\mathrm{GO}$ exhibits two main intrinsic peaks: the $\mathrm{D}$ band (at $\sim 1350 \mathrm{~cm}^{-1}$ ), arising from a breathing mode of k-point photons of $\mathrm{A}_{1 \mathrm{~g}}$ symmetry; and the $\mathrm{G}$ band (at $\sim 1600 \mathrm{~cm}^{-1}$ ) originating from the first-order scattering of $\mathrm{E}_{2 \mathrm{~g}}$ phonon of $\mathrm{sp}^{2}$ carbon atoms. Raman spectrum of RGO also shows two other bands, a $2 \mathrm{D}$ band at $\sim 2700 \mathrm{~cm}^{-1}$ and the $\mathrm{S}^{3}$ band at $\sim 2900 \mathrm{~cm}^{-1}$, showing the graphitization the carbon framework. At the same time, an increased $\mathrm{I}_{\mathrm{D}} / \mathrm{I}_{\mathrm{G}}$ ratio is attributable to a lower degree of crystallinity in graphitic materials and usually reflects the order of defects in $\mathrm{GO}$ or graphene that indicate a decrease in 


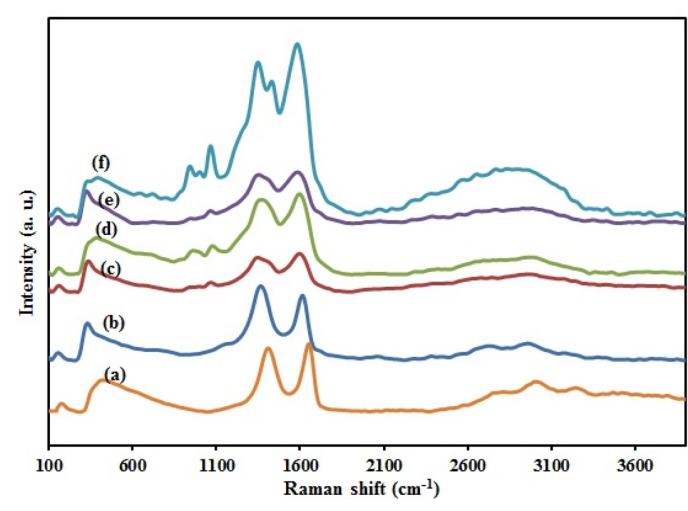

Fig. 2. Raman spectrum of the (a) GO, (b) RGO, (c) PPy/ $\mathrm{RGO}$, (d) $\mathrm{ZnO} / \mathrm{PPy} / \mathrm{RGO}$, (e) $\mathrm{Cu}_{\mathrm{x}} \mathrm{O} / \mathrm{PPy} / \mathrm{RGO}$, and (f) $\mathrm{Cu}_{\mathrm{x}} \mathrm{O}-\mathrm{ZnO} / \mathrm{PPy} / \mathrm{RGO}$

the size of the in-plane $\mathrm{sp}^{2}$ domains and a partially ordered crystal structure of the graphene. The calculated $\mathrm{I}_{\mathrm{D}} / \mathrm{I}_{\mathrm{G}}$ was 0.92 and 1.13 in Fig. 2a and b, respectively for $\mathrm{GO}$ and RGO. So because of increase in the ratio, it was proved that $\mathrm{GO}$ was successfully reduced to RGO. In the case of PPy/RGO (Fig. 2c), the characteristic Raman bands with a maximum at $\sim 1000 \mathrm{~cm}^{-1}$ are assigned to the $\mathrm{C}-\mathrm{H}$ in-plane deformation vibrations. The band at $\sim 900 \mathrm{~cm}^{-1}$ belongs to in-plane deformations of the pyrrole ring in a dictation-bearing unit. As shown in Fig. 2d stretching modes of $\mathrm{C}=\mathrm{C}$ are shifted to lower wavenumbers because of the incorporation of $\mathrm{ZnO}$. Fig. 2e indicates the Raman spectra of the stretching modes of $\mathrm{C}=\mathrm{C}$ that are shifted to lower wavenumbers. These red shifts may be due to the incorporation of $\mathrm{CuO}$ and $\mathrm{Cu}_{2} \mathrm{O}$ into PPy nanofibers. Fig. $2 \mathrm{f}$ indicates that the main characteristic bands of $\mathrm{RGO}, \mathrm{PPy}, \mathrm{ZnO}$, and $\mathrm{Cu}_{\mathrm{x}} \mathrm{O}$ all appear in raman spectra of $\mathrm{Cu}_{\mathrm{x}} \mathrm{O}-\mathrm{ZnO} / \mathrm{PPy} /$ $\mathrm{RGO}$ nanocomposite. In the case of $\mathrm{Cu}_{\mathrm{x}} \mathrm{O} / \mathrm{PPy} / \mathrm{RGO}$, $\mathrm{ZnO} / \mathrm{PPy} / \mathrm{RGO}$, and $\mathrm{Cu}_{\mathrm{x}} \mathrm{O}-\mathrm{ZnO} / \mathrm{PPy} / \mathrm{RGO}$, the bands are observed at the frequency lower than $600 \mathrm{~cm}^{-1}$ attributed to metal oxide vibration modes. Also compared to $\mathrm{RGO}, \mathrm{Cu}_{\mathrm{x}} \mathrm{O}-\mathrm{ZnO} / \mathrm{PPy} / \mathrm{RGO}$ nanocomposites show two differences in the Raman spectra. First, the calculated $\mathrm{I}_{\mathrm{D}} / \mathrm{I}_{\mathrm{G}}$ of the samples $\mathrm{Cu}_{\mathrm{x}} \mathrm{O}-\mathrm{ZnO} / \mathrm{PPy} / \mathrm{RGO}$ (0.94) was lower than that of RGO (1.13), indicating a lower density of defects present in $\mathrm{Cu}_{\mathrm{x}} \mathrm{O}-\mathrm{ZnO} / \mathrm{PPy} /$ RGO. Second, the shift toward lower frequencies from $\mathrm{RGO}$ to $\mathrm{Cu}_{\mathrm{x}} \mathrm{O}-\mathrm{ZnO} / \mathrm{PPy} / \mathrm{RGO}$ nanocomposite in Raman bands shows the interfacial strapping amalgamation of $\mathrm{Cu}_{\mathrm{x}} \mathrm{O}-\mathrm{ZnO}$ nanoparticles with the PPy film

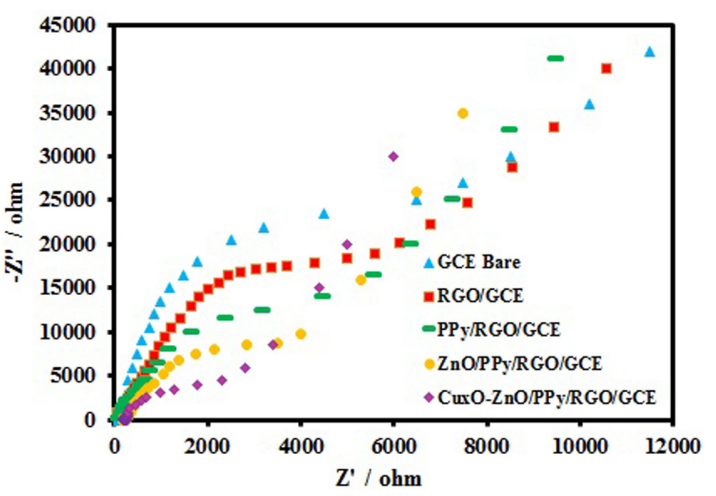

Fig. 3. EIS plots of the bare GCE, RGO/GCE, PPy/RGO/ GCE, $\mathrm{ZnO} / \mathrm{PPy} / \mathrm{RGO} / \mathrm{GCE}$ and $\mathrm{CuxO}-\mathrm{ZnO} / \mathrm{PPy} / \mathrm{RGO} / \mathrm{GCE}$ in $0.1 \mathrm{M} \mathrm{KCl}$ solution containing $5.0 \mathrm{mM} \mathrm{Fe}(\mathrm{CN})_{6}^{3-/ 4-}$.

and clearly credited to the deposition of $\mathrm{Cu}_{\mathrm{x}} \mathrm{O}-\mathrm{ZnO}$ nanoparticles on the surface of PPy films and the $\pi-\pi$ interactions between $\mathrm{PPy}$ and $\mathrm{Cu}_{\mathrm{x}} \mathrm{O}-\mathrm{ZnO}$ nanoparticles [39-41]. Raman results indicate that exfoliated RGO sheets, PPy nanofibers, and $\mathrm{Cu}_{\mathrm{x}} \mathrm{O}-\mathrm{ZnO}$ nanocrystals coexist in the prepared nanocomposite.

The technique of EIS is effective to monitor the surface features, which could be used as a parameter to understand the chemical transformations and processes associated with the conductive surface [42]. A typical impedance spectrum includes a semicircle portion at higher frequencies corresponding to the electron transfer-limited process and a linear part at lower frequency range representing the diffusionlimited process. The semicircle diameter corresponds to the electron-transfer resistance (Rct), which can be used to describing the interface properties of the electrode. The experiment was carried out in $1: 1$ mixture of $0.1 \mathrm{M} \mathrm{KCl}$ and $5 \mathrm{mM} \mathrm{K}_{3} \mathrm{Fe}(\mathrm{CN})_{6}$ solution over the frequency range $100 \mathrm{kHz}$ to $10 \mathrm{mHz}$. The resulting Nyquist plots observed for the unmodified GCE, RGO/GCE, PPy/RGO/GCE, ZnO/ $\mathrm{PPy} / \mathrm{RGO} / \mathrm{GCE}$, and $\mathrm{Cu}_{\mathrm{x}} \mathrm{O}-\mathrm{ZnO} / \mathrm{PPy} / \mathrm{RGO} / \mathrm{GCE}$ are shown in Fig. 3. The Rct values are found to be about $8800,7200,5900,4200$ and $1900 \Omega$ for unmodified GCE, RGO/GCE, PPy/RGO/GCE, ZnO/PPy/RGO/ $\mathrm{GCE}$, and $\mathrm{Cu}_{\mathrm{x}} \mathrm{O}-\mathrm{ZnO} / \mathrm{PPy} / \mathrm{RGO} / \mathrm{GCE}$, respectively. Lower Rct value of $\mathrm{Cu}_{\mathrm{x}} \mathrm{O}-\mathrm{ZnO} / \mathrm{PPy} / \mathrm{RGO} / \mathrm{GCE}$ suggested $\mathrm{Cu}_{\mathrm{x}} \mathrm{O}-\mathrm{ZnO} / \mathrm{PPy} / \mathrm{RGO}$ nanocomposite might form a smooth electron conduction pathway on the electrode that facilitates smooth electron transfer. This may be ascribed to the high surface area and bet- 
ter conductivity of $\mathrm{Cu}_{\mathrm{x}} \mathrm{O}-\mathrm{ZnO} / \mathrm{PPy} / \mathrm{RGO}$. This is supported by the morphological observation which suggested that in $\mathrm{PPy} / \mathrm{RGO} / \mathrm{GCE}$ is having highly ordered PPy nanofibers on the surface of RGO/GCE whereas $\mathrm{Cu}_{\mathrm{x}} \mathrm{O}-\mathrm{ZnO} / \mathrm{PPy} / \mathrm{RGO} / \mathrm{GCE}$, the surface of GCE is covered with $\mathrm{Cu}_{\mathrm{x}} \mathrm{O}-\mathrm{ZnO}$ nanoparticles patterned PPy nanofibers.

\subsection{Electrochemical behaviors of AA, DA, UA,} and FA at different electrodes

In Fig. 4, the cyclic voltammograms of the $500 \mu \mathrm{M}$ AA, $500 \mu \mathrm{M}$ DA, $200 \mu \mathrm{M}$ UA, and $200 \mu \mathrm{M}$ FA at GCE, RGO/GCE, PPy/RGO/GCE, ZnO/PPy/RGO/ $\mathrm{GCE}, \mathrm{Cu}_{\mathrm{x}} \mathrm{O} / \mathrm{PPy} / \mathrm{RGO} / \mathrm{GCE}$, and $\mathrm{Cu}_{\mathrm{x}} \mathrm{O}-\mathrm{ZnO} / \mathrm{PPy} /$ $\mathrm{RGO} / \mathrm{GCE}$ were recorded in $0.1 \mathrm{M}$ Phosphate buffer (PBS) solution. At bare GCE (Fig. 4a), AA and FA had no clear peak, and the anodic peaks of DA and UA appeared at 0.35 and $0.61 \mathrm{~V}$, respectively. The distinction of oxidation potential among them was not clear. Therefore, it is very important to measure simultaneously these species without interferences. Fig. $4 \mathrm{~b}$, at the surface of RGO/GCE the shapes of peaks is better. This is due to the unique electronic structure of RGO that accelerate the electron transfer. AA, UA, and FA had an irreversible peak at 0.45 , 0.56 , and $0.84 \mathrm{~V}$, respectively. DA had a couple of redox peaks with the anodic and cathodic peak potential at $0.30 \mathrm{~V}$ and $0.16 \mathrm{~V}$, respectively. In this case, the oxidation peak potentials of four species are very close to each other yet. Therefore, we decided to modify this electrode by PPy nanofibers. In Fig. 4c you see the peaks of four species at the surface of PPy/RGO/GCE. AA, UA, and FA had an irreversible peak at $0.30,0.51$, and $0.80 \mathrm{~V}$, respectively. DA had a couple of redox peaks with the anodic and cathodic peak potential at $0.22 \mathrm{~V}$ and $0.10 \mathrm{~V}$, respectively. It is clear that the peaks potentials shifted toward minus value and the currents have increased, this notably enhanced electrochemical activity of $\mathrm{RGO} / \mathrm{GCE}$ was related to the unique electronic properties of PPy/RGO. As shown in Fig. 4d, AA, DA, $\mathrm{UA}$ and FA exhibited more negative oxidation potential on $\mathrm{Cu}_{\mathrm{x}} \mathrm{O} / \mathrm{PPy} / \mathrm{RGO} / \mathrm{GCE}(0.18,0.18,0.47$ and $0.76 \mathrm{~V})$, respectively and on $\mathrm{ZnO} / \mathrm{PPy} / \mathrm{RGO} / \mathrm{GCE}$ (0.03, 0.09, 0.39 and $0.61 \mathrm{~V})$, respectively (Fig. 4e). The peak potential separation of DA on $\mathrm{Cu}_{\mathrm{x}} \mathrm{O} / \mathrm{PPy} /$ $\mathrm{RGO} / \mathrm{GCE}$, and $\mathrm{ZnO} / \mathrm{PPy} / \mathrm{RGO} / \mathrm{GCE}$ was $150 \mathrm{mV}$ and $10 \mathrm{mV}$, respectively. Finally, at the surface of $\mathrm{Cu}_{\mathrm{x}} \mathrm{O}-\mathrm{ZnO} / \mathrm{PPy} / \mathrm{RGO} / \mathrm{GCE}$ (Fig. 4f), the anodic peaks for oxidation of AA, UA, and FA appeared at $0.03,0.45$, and $0.7 \mathrm{~V}$ respectively. DA showed a couple of well-shaped redox peaks with the anodic and cathodic peak potential at $0.14 \mathrm{~V}$ and $0.06 \mathrm{~V}$, respectively. Improved kinetics for the oxidation of the four biomolecules at $\mathrm{Cu}_{\mathrm{x}} \mathrm{O}-\mathrm{ZnO} / \mathrm{PPy} / \mathrm{RGO} / \mathrm{GCE}$ surface is attributed to the Zinc oxide-copper oxide $p-n$ junc-
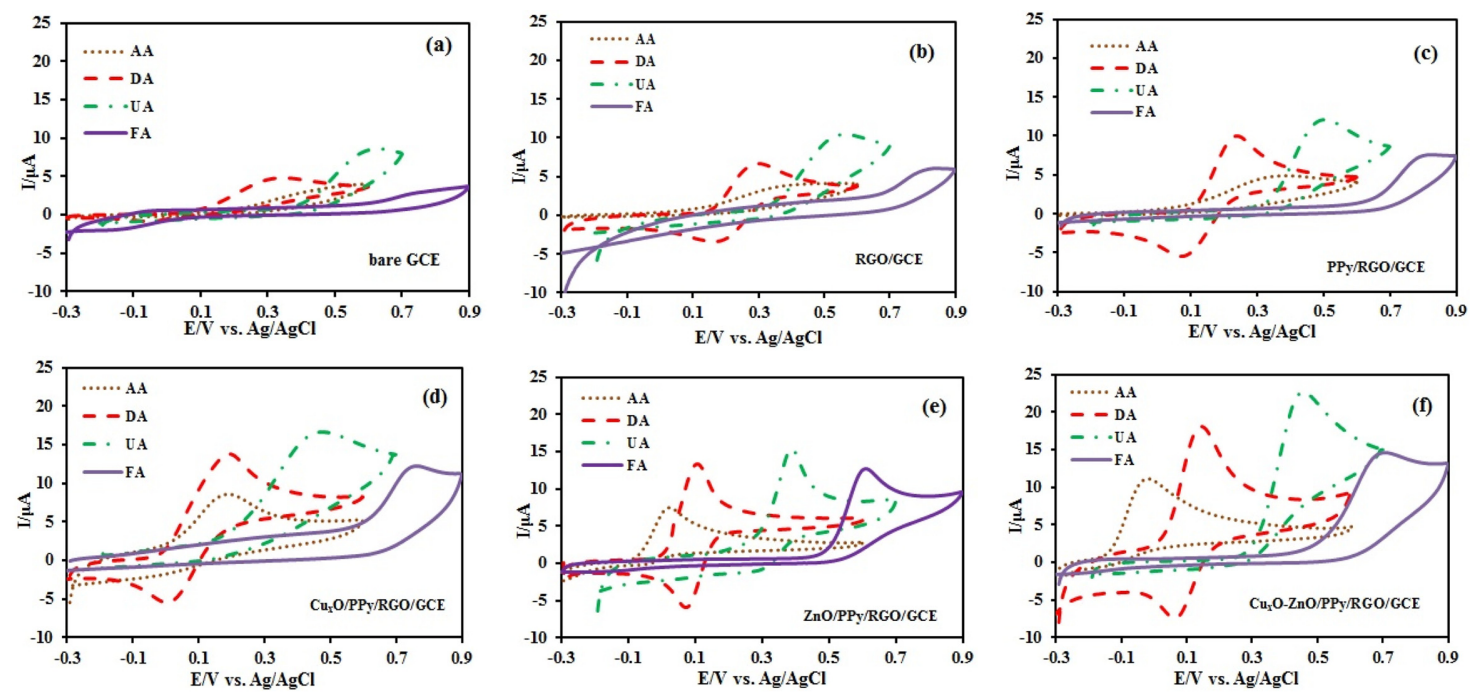

Fig. 4. Cyclic voltammograms of the $500 \mu \mathrm{M}$ AA, $500 \mu \mathrm{M}$ DA, $200 \mu \mathrm{M}$ UA and $200 \mu \mathrm{M}$ FA at the bare GCE (a), RGO/ GCE (b), PPy/RGO/GCE (c), $\mathrm{Cu}_{\mathrm{x}} \mathrm{O} / \mathrm{PPy} / \mathrm{RGO} / \mathrm{GCE}$ (d), $\mathrm{ZnO} / \mathrm{PPy} / \mathrm{RGO} / \mathrm{GCE}$ (e), and $\mathrm{Cu}_{\mathrm{x}} \mathrm{O}-\mathrm{ZnO} / \mathrm{PPy} / \mathrm{RGO} / \mathrm{GCE}$ (f) in $0.1 \mathrm{M}$ PBS (pH 7.0) at a scan rate of $100 \mathrm{mV} \mathrm{s}^{-1}$. 
tion heterostructures. Separation values of the oxidation peak potentials for AA-DA, DA-UA, and UAFA were approximately $170 \mathrm{mV}, 310 \mathrm{mV}$, and $250 \mathrm{mV}$, respectively.

\subsection{The influence of scan rates}

The relation between scan rate and the electrochemical behaviors of $500 \mu \mathrm{M}$ AA, $500 \mu \mathrm{M}$ DA, $200 \mu \mathrm{M}$ UA, and $200 \mu \mathrm{M}$ FA in $0.1 \mathrm{M}$ PBS ( $\mathrm{pH}=$ 7.0) was investigated. The cyclic voltammograms with different scan rates in the range of 10 to $100 \mathrm{mV} \mathrm{s}^{-1}$ at the $\mathrm{Cu}_{\mathrm{x}} \mathrm{O}-\mathrm{ZnO} / \mathrm{PPy} / \mathrm{RGO} / \mathrm{GCE}$ are shown in Fig. 5(A-D) for AA, DA, UA, and FA, respectively. In the case of AA, DA, UA, and FA, the peak currents showed a linear relationship with the square root of the scan rate (Insets (a) in Fig. 5), indicating the diffusion controlled process dominated for AA, DA, $\mathrm{UA}$, and FA, because of the fast electron transfer rate on nanocomposite. As shown in Fig. 5, the following linear relationships were observed: $i_{p}$ $(\mu \mathrm{A})=1.008( \pm 0.032) v^{1 / 2}(\mathrm{mV} / \mathrm{s})-1.321( \pm 0.251), \mathrm{i}_{\mathrm{p}}$ $(\mu \mathrm{A})=1.944( \pm 0.052) v^{1 / 2}(\mathrm{mV} / \mathrm{s})^{1 / 2}-2.034( \pm 0.371)$, $\mathrm{i}_{\mathrm{p}}(\mu \mathrm{A})=2.189( \pm 0.061) \quad v^{1 / 2}(\mathrm{mV} / \mathrm{s})^{1 / 2}+$ $0.103( \pm 0.455), \mathrm{i}_{\mathrm{p}}(\mu \mathrm{A})=1.453( \pm 0.042) v^{1 / 2}(\mathrm{mV} / \mathrm{s})^{1 / 2}$ $-0.452( \pm 0.331)$ for AA, DA, UA, and FA, respectively and the plot showed good linearity, with a correlation coefficient of $0.9908,0.9946,0.9937$, and 0.9926 for AA, DA, UA, and FA, respectively.

In a further investigation of the effect of scan rates on peak potential for DA (inset b of Fig. 5B), it was found that the oxidation peak potential $\left(\mathrm{E}_{\mathrm{pa}}\right)$ shifted positively and the reduction peak potential $\left(\mathrm{E}_{\mathrm{pc}}\right)$ shifted negatively with the increasing of the scan rates and the redox peak potential $\left(\mathrm{E}_{\mathrm{p}}\right)$ is linear to the natural logarithm of scan rate (lnv) at the rates of 10$50 \mathrm{mV} \mathrm{s}^{-1}$. By considering Laviron theory, the electron-transfer coefficient $(\alpha)$ and electron-transfer rate constant $\left(\mathrm{K}_{\mathrm{s}}\right)$ have been calculated as follows [43]:

$$
\begin{aligned}
E_{p c}= & E^{o \prime}-\left(\frac{R T}{\alpha n F}\right) \ln v \\
E_{p a}= & E^{o \prime}+\left(\frac{R T}{(1-\alpha) n F}\right) \ln v \\
\log K_{s}= & \alpha \log (1-\alpha)+(1-\alpha) \log \alpha \\
& -\log \left(\frac{R T}{n F v}\right)-(1-\alpha) \frac{\alpha F \Delta E_{p}}{2.3 R T}
\end{aligned}
$$

where $v$ is the scan rate, $\mathrm{n}$ is the electron transfer number, $\mathrm{T}=298 \mathrm{~K}, \mathrm{R}=8.314 \mathrm{~J} \mathrm{~mol}^{-1} \mathrm{~K}^{-1}$ and $\mathrm{F}$
$=96485 \mathrm{C} \mathrm{mol}^{-1}, E^{o \prime}$ is the formal potential. The slopes of the linear regression equations are in accordance with RT/ $(1-\alpha) n F$ and RT/ $\alpha \mathrm{nF}$, for anodic and cathodic reactions, respectively. The linear regression equations calculated were $\mathrm{E}_{\mathrm{pa}}=0.014( \pm 0.004)+$ $0.033( \pm 0.001) \operatorname{lnv}, \mathrm{R}^{2}=0.9954 ; \mathrm{E}_{\mathrm{pc}}=0.092( \pm 0.005)-$ $0.028( \pm 0.001) \operatorname{lnv}, \mathrm{R}^{2}=0.9908$. The charge transfers coefficient $(\alpha)$ and the number of electrons (n) were calculated according to Eqs (1) and (2) to be 0.53 and 1.68 , respectively. Under these conditions, the $\mathrm{k}_{\mathrm{s}}$ of DA can also be calculated using Eq (3) to be $\mathrm{k}_{\mathrm{s}}=0.162 \mathrm{~cm}$ $\mathrm{s}^{-1}$. According to the kinetics of the electrode process, when the rate constant is larger than $10^{-2} \mathrm{~cm} \mathrm{~s}^{-1}$, the electron-transfer process is quite fast, and the electrode reaction is reversible. Thus, the above result reveals that the redox reaction process of DA is reversible.

According to the Laviron theory for an irreversible electrode process, $E_{p}$ is calculated by the following equation [44]:

$$
E_{p}=E^{o^{\prime}}-\left(\frac{R T}{\alpha n F}\right) \ln \left(\frac{R T K_{s}}{\alpha n F}\right)+\left(\frac{R T}{\alpha n F}\right) \ln v
$$

The equations of the plots are $\mathrm{E}_{\mathrm{pa}}=0.025( \pm 0.002)$ $\ln v-0.138( \pm 0.006)\left(\mathrm{R}^{2}=0.9859\right), \mathrm{E}_{\mathrm{pa}}=$ $0.026( \pm 0.001) \ln v+0.353( \pm 0.003)\left(\mathrm{R}^{2}=0.9962\right)$ and $\mathrm{E}_{\mathrm{pa}}=0.035( \pm 0.001) \ln \mathrm{v}+0.537( \pm 0.005)\left(\mathrm{R}^{2}=\right.$ 0.9928 ) for AA, UA, and FA, respectively. From the slope of the $E_{p}$ versus $\ln v$ plot (inset b of Figures A, C and D), $\alpha$ and $n$ were calculated. The $\alpha n$ value of these molecules was calculated as $1.02,0.99$ and 0.85 . If we assume $\alpha=0.5$, which is used for irreversible redox reactions, the number of electrons transferred in oxidation processes of AA, UA and FA were found to be $2.05,1.97$ and 1.71 , respectively, that assuming $n=2$.

In order to understand the oxidation mechanism of AA, DA, UA, and FA on the $\mathrm{Cu}_{\mathrm{x}} \mathrm{O}-\mathrm{ZnO} / \mathrm{PPy} / \mathrm{RGO} /$ GCE, current function analysis (1) along with the dependence on the scan rate was carried out [45].

$$
\psi=\frac{i_{p}}{n F A D^{1 / 2} C^{*}\left(\frac{n F v}{R T}\right)^{1 / 2}}
$$

As $I_{\mathrm{Pa}} v^{-1 / 2}$ is proportional to $\psi$ the first relationship can be studied as if it were $\psi$ vs. v $[46,47]$. From inset $\mathrm{c}$ of Fig. $5 \mathrm{~B}$, it can be observed that the curve for DA shows a slightly negative slope that could be interpreted as a reversible charge transfer along with irreversible chemical reaction $[48,49]$. Fig. 5B (inset 

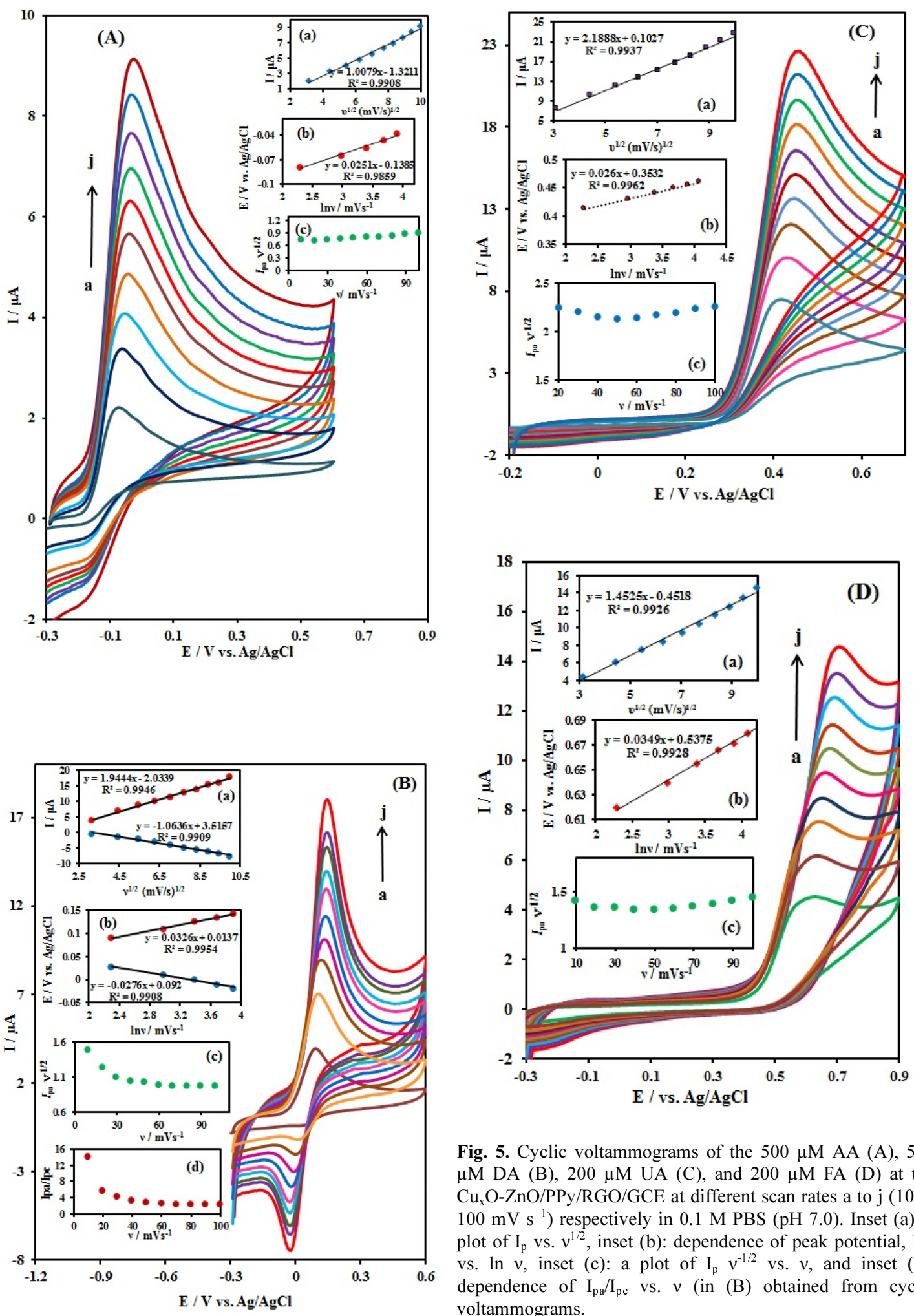

Fig. 5. Cyclic voltammograms of the $500 \mu \mathrm{M}$ AA (A), 500 $\mu \mathrm{M}$ DA (B), $200 \mu \mathrm{M}$ UA (C), and $200 \mu \mathrm{M}$ FA (D) at the $\mathrm{Cu}_{\mathrm{x}} \mathrm{O}-\mathrm{ZnO} / \mathrm{PPy} / \mathrm{RGO} / \mathrm{GCE}$ at different scan rates a to $\mathrm{j}(10$ to $100 \mathrm{mV} \mathrm{s}^{-1}$ ) respectively in $0.1 \mathrm{M}$ PBS (pH 7.0). Inset (a): a plot of $I_{p} v s . v^{1 / 2}$, inset (b): dependence of peak potential, $E_{p}$, vs. $\ln v$, inset (c): a plot of $I_{p} v^{-1 / 2}$ vs. $v$, and inset (d): dependence of $I_{p a} / I_{p c}$ vs. $v$ (in (B) obtained from cyclic voltammograms. 
d) shows the $\mathrm{I}_{\mathrm{Pa}} / \mathrm{I}_{\mathrm{Pc}}$ vs. v plot. From the analysis of the ratio $\mathrm{I}_{\mathrm{Pa}} / \mathrm{I}_{\mathrm{Pc}}$ for modified electrode it can be observed that the $\mathrm{I}_{\mathrm{Pa}} / \mathrm{I}_{\mathrm{Pc}}$ ratio is about 2.4 , and the cathodic wave is smaller than the anodic process indicating that the oxidized product is not stable and probably decomposes or undergoes a subsequent chemical reaction that prevents to be reduced to the original reagent. This result complements the analysis from $\mathrm{I}_{\mathrm{pa}} v^{-1 / 2} v s$. $v$.

On the other hand, AA, UA, and FA (inset $\mathrm{c}$ of Fig. 5(A,C and D) ) shows a slightly positive slope according to an irreversible charge transfer and exhibits a characteristic shape typical of an EC (The symbols (E) and (C) represent the electrochemical and chemical reactions) process [50]. These results signify that the overall electrochemical oxidation of AA, UA, and FA at a modified electrode might be controlled by a cross-exchange process operating between the redox site of the $\mathrm{Cu}_{\mathrm{x}} \mathrm{O}-\mathrm{ZnO} / \mathrm{PPy} / \mathrm{RGO} / \mathrm{GCE}$ and these compounds and the diffusion of them.
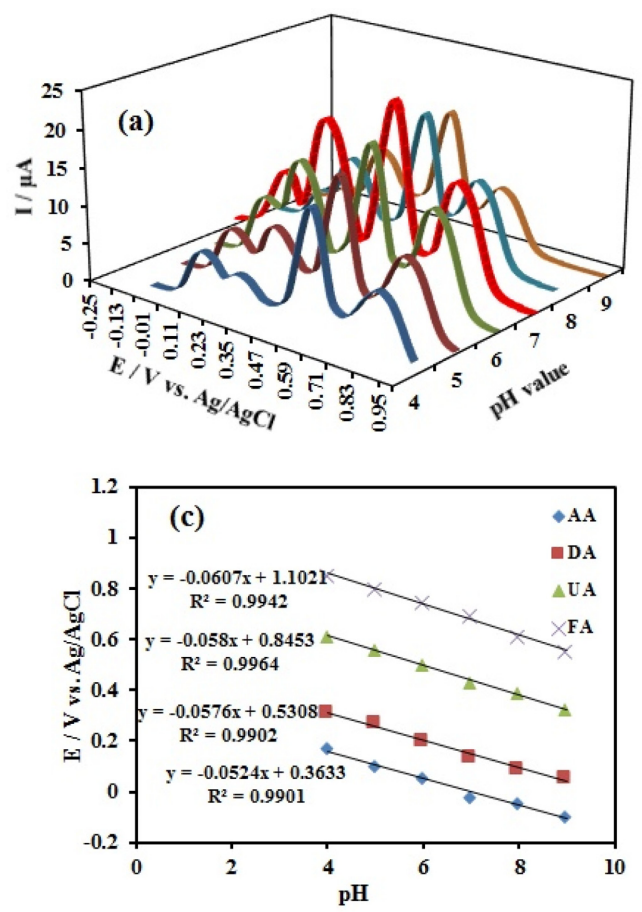

3.4 Optimization of pH for AA, DA, UA, and FA detection at $\mathrm{Cu}_{\mathrm{x}} \mathrm{O}-\mathrm{ZnO} / \mathrm{PPy} / \mathrm{RGO} / \mathrm{GCE}$

The $\mathrm{pH}$ of supporting electrolyte had a significant influence on the AA, DA, UA, and FA electro-oxidation at the $\mathrm{Cu}_{\mathrm{x}} \mathrm{O}-\mathrm{ZnO} / \mathrm{PPy} / \mathrm{RGO} / \mathrm{GCE}$ because it affects both peak potential and current. The Fig. 6 show over the $\mathrm{pH}$ range 4-9 in phosphate buffer. The effect of solution $\mathrm{pH}$ on the electrochemical behavior in the simultaneous determination of these species was studied using $\mathrm{CV}$ method for each species separately (Fig. S5) and DPV method in the mixture (Fig. 6). The oxidation peak currents for all four compounds increased gradually as raising $\mathrm{pH}$, and peaked at $\mathrm{pH} 7.0$ and then reduced significantly with the increase of $\mathrm{pH}$. With due attention to the obtained results, $\mathrm{pH} 7.0$ was chosen as an optimum solution $\mathrm{pH}$ for further experiments. As shown in Fig. S5 (ad), the peak potential of four biologic molecules shifted toward less positive value as $\mathrm{pH}$ of the medium was increased. Since pH 7.0 is the physiological $\mathrm{pH}$ and four molecules had maximum current
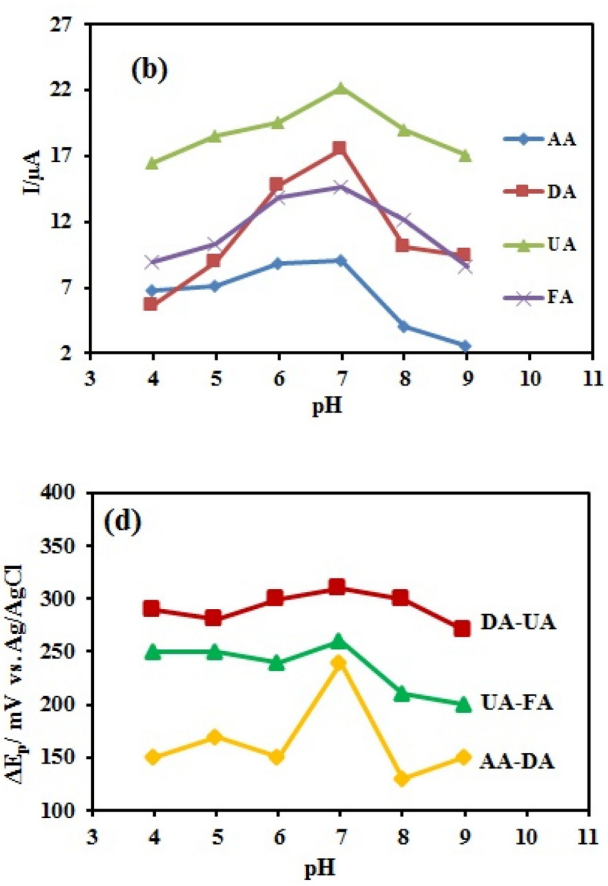

Fig. 6. (a) DPVs of a mixture of $500 \mu \mathrm{M} A A, 500 \mu \mathrm{M}$ DA, $200 \mu \mathrm{M}$ UA and $200 \mu \mathrm{M}$ FA at the $\mathrm{Cu}$ O-ZnO/PPy/RGO/GCE with different $\mathrm{pH}$ values of 4.0-9.0; plots of the peak currents (b) and peak potentials (c) for AA, DA, UA and FA as function of solution $\mathrm{pH},(\mathrm{d})$ Effects of $\mathrm{pH}$ on peak separation potential $\left(\Delta \mathrm{E}_{\mathrm{pa}}\right)$ for the electro oxidation of DA and UA, UA and FA, or AA and DA. 
in $\mathrm{pH} 7.0$ we choose this $\mathrm{pH}$ for electrochemical detection. The oxidation peak potentials of AA, DA, UA and FA obey the following equations: $\mathrm{E}_{\mathrm{pa}}=-$ $0.052( \pm 0.003) \mathrm{pH}+0.363( \pm 0.020)\left(\mathrm{R}^{2}=0.9901\right), \mathrm{E}_{\mathrm{pa}}=-$ $0.058( \pm 0.003) \mathrm{pH}+0.531( \pm 0.018)\left(\mathrm{R}^{2}=0.9902\right), \mathrm{E}_{\mathrm{pa}}=-$ $0.058( \pm 0.002) \mathrm{pH}+0.845( \pm 0.012)\left(\mathrm{R}^{2}=0.9964\right)$, and $\mathrm{E}_{\mathrm{pa}}=-0.061( \pm 0.002) \mathrm{pH}+1.102( \pm 0.016)\left(\mathrm{R}^{2}=0.9942\right)$, respectively. For these species, the slope is near to Nernstian slope that indicates in four reactions the number of transferred protons and electrons are equal.

The effect of solution $\mathrm{pH}$ was examined by DPV method in a mixture of four compounds that are shown in Fig. 6a. As shown, in this case, the oxidation peak currents for four analytes increased from $\mathrm{pH} 4.0$ to 7.0 and then decreased with $\mathrm{pH}$ changes from 7.0 to 10.0 (Fig. 6b). Therefore, the PBS with a $\mathrm{pH}$ of 7.0 was selected as an optimal supporting electrolyte for the simultaneous electrochemical determination of AA, DA, UA, and FA in the mixture. Also, the results showed that the corresponding anodic peak potentials $\left(\mathrm{E}_{\mathrm{pa}}\right)$ of AA, DA, UA, and FA were changed linearly with variation in $\mathrm{pH}$ solution (Fig. $6 \mathrm{c})$. In the $\mathrm{pH}, 7.0$ separation values of the oxidation peak potentials for AA-DA, DA-UA, and UA-FA were approximately $240 \mathrm{mV}, 310 \mathrm{mV}$, and $260 \mathrm{mV}$, respectively (Fig. 6d).

\subsection{Simultaneous determination of AA, DA, UA and FA}

Sensitivity and selectivity of an electrode (III) for the simultaneous determination of AA, DA, UA, and FA were evaluated for a mixture of these species at $\mathrm{Cu}_{\mathrm{x}} \mathrm{O}-\mathrm{ZnO} / \mathrm{PPy} / \mathrm{RGO} / \mathrm{GCE}$. Fig. 7 shows the Differential pulse voltammograms, DPVs, recorded for a mixture of AA $(500 \mu \mathrm{M})$, DA $(500 \mu \mathrm{M})$, UA $(200 \mu \mathrm{M})$, and FA $(200 \mu \mathrm{M})$ in $0.1 \mathrm{M}$ PBS $(\mathrm{pH} 7.0)$ at GCE, RGO/GCE, PPY/RGO/GCE, ZnO/PPy/ $\mathrm{RGO} / \mathrm{GCE}, \mathrm{Cu}_{\mathrm{x}} \mathrm{O} / \mathrm{PPy} / \mathrm{RGO} / \mathrm{GCE}$ and $\mathrm{Cu}_{\mathrm{x}} \mathrm{O} / \mathrm{ZnO} /$ $\mathrm{PPy} / \mathrm{RGO} / \mathrm{GCE}$. The results showed that the oxidation peaks of AA, DA, UA, and FA are indistinguishable and broad at the bare GCE, RGO/GCE and PPy/ $\mathrm{RGO} / \mathrm{GCE}$. On the other hand, the oxidation peak potentials of DA, UA, and FA separate into three well-defined peaks using $\mathrm{ZnO} / \mathrm{PPy} / \mathrm{RGO} / \mathrm{GCE}$, and $\mathrm{Cu}_{\mathrm{x}} \mathrm{O} / \mathrm{PPy} / \mathrm{RGO} / \mathrm{GCE}$ but the oxidation peak of ascorbic acid cannot be seen. At the $\mathrm{Cu}_{\mathrm{x}} \mathrm{O} / \mathrm{ZnO} / \mathrm{PPy} /$ $\mathrm{RGO} / \mathrm{GCE}$, four oxidation peaks corresponding AA, DA, UA, and FA were observed, indicating that their oxidation takes place independently at the modified

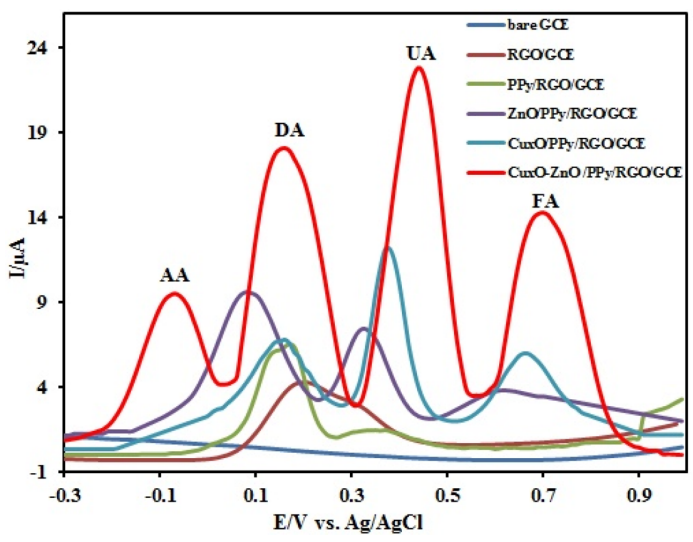

Fig. 7. DPVs of a mixture of $500 \mu \mathrm{M}$ AA, $500 \mu \mathrm{M}$ DA, $200 \mu \mathrm{M}$ UA and $200 \mu \mathrm{M} \mathrm{FA}$; at the surface of a bare GCE, RGO/GCE, PPy/RGO/GCE, ZnO/ PPy/RGO/GCE, $\mathrm{Cu}_{\mathrm{x}} \mathrm{O} /$ $\mathrm{PPy} / \mathrm{RGO} / \mathrm{GCE}$, and $\mathrm{Cu}_{\mathrm{x}} \mathrm{O} / \mathrm{ZnO} / \mathrm{PPy} / \mathrm{RGO} / \mathrm{GCE}$. DPV experimental conditions: pulse amplitude of $50 \mathrm{mV}$, pulse time of $100 \mathrm{~ms}$, sweep rate of $50 \mathrm{mV} \mathrm{s}^{-1}$; in $0.1 \mathrm{M} \mathrm{PBS}$ solution ( $\mathrm{pH} 7.0)$.

electrode. In addition, the separations of the DPV peak potentials and calculated to be $230 \mathrm{mV}, 270 \mathrm{mV}$, and $260 \mathrm{mV}$ between AA-DA, DA-UA, and UA-FA, respectively. The separations were large enough to allow selectively determining AA, DA, UA, and FA simultaneously in their mixture solution. The $\mathrm{I}_{\mathrm{pa}}$ of AA, DA, UA, and FA were $9.5 \mu \mathrm{A}, 13.9 \mu \mathrm{A}, 19.7 \mu \mathrm{A}$, and $11.1 \mu \mathrm{A}$, which were all much larger than other electrodes, respectively. The obtained results also indicate that simultaneous determination of AA, DA, UA, and FA could be achieved with sensitivity and selectivity.

The DPV method was used for the deep study of the simultaneous determination of AA, DA, UA, and FA because it has much higher sensitivity and a better resolution compared to $\mathrm{CV}$ method for quantitative analysis. The results are shown in Fig. 8. In a quadruple mixture, the concentration of one compound changed, and those of other three compounds remained constant.

The peak current of AA in 0.1 M PBS ( $\mathrm{pH} 7.0$ ) containing $500 \mu \mathrm{M}$ DA, $200 \mu \mathrm{M} U A$, and $200 \mu \mathrm{M}$ FA increased linearly with the concentration increase of the AA from 0.07 to $485 \mu \mathrm{M}$ (Fig. 8A). The following linear equations is $\mathrm{I}_{\mathrm{p}}, \mathrm{AA}_{\mathrm{A}}(\mu \mathrm{A})=0.600( \pm$ $0.091)+0.019( \pm 0.001) \mathrm{C}_{\mathrm{AA}}(\mu \mathrm{M})\left(\mathrm{R}^{2}=0.9944\right)$. Similarly, as shown in Fig. 8B, the oxidation peak current of DA in $0.1 \mathrm{M}$ PBS containing $500 \mu \mathrm{M} \mathrm{AA}$, 

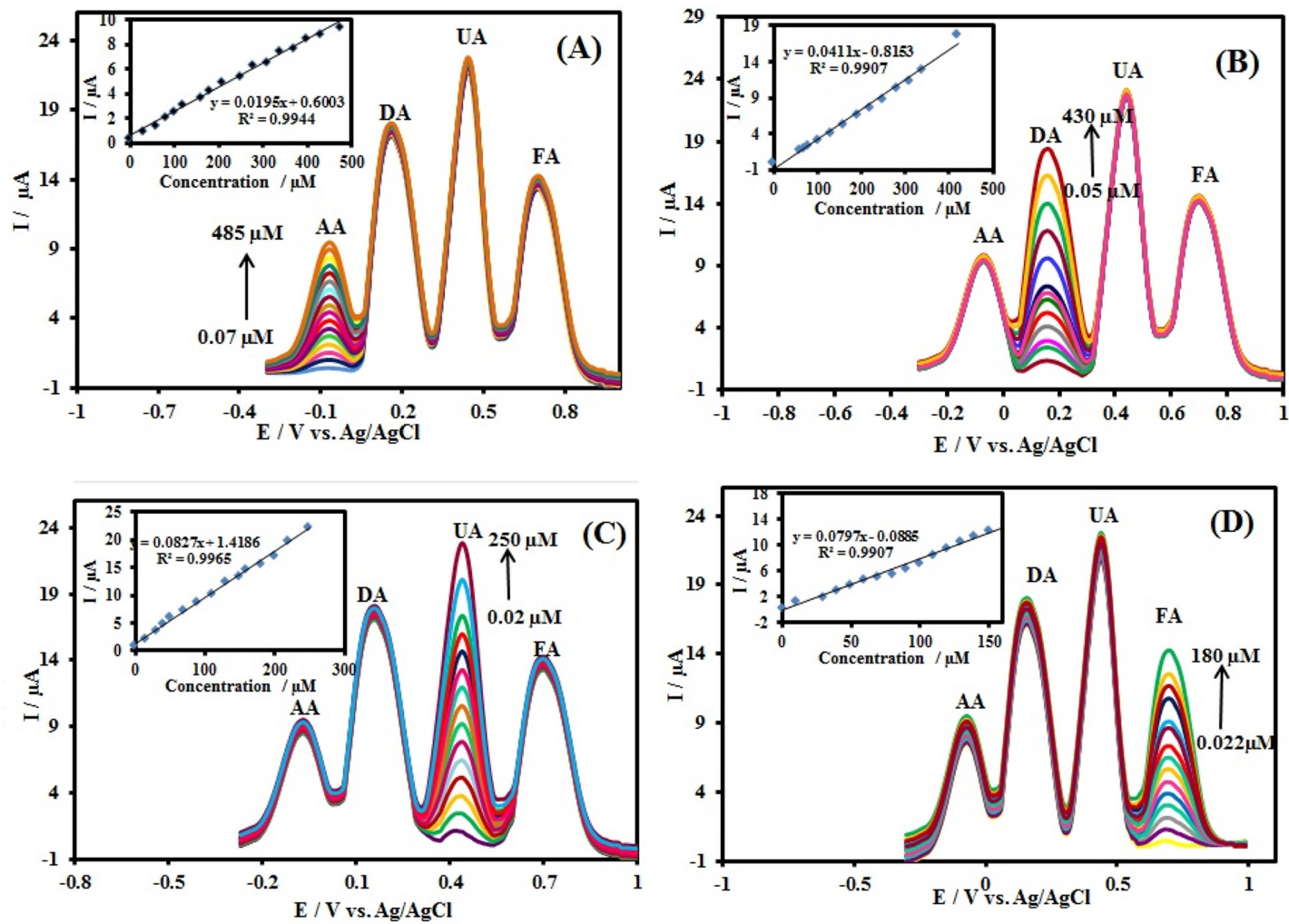

Fig. 8. DPVs of (A) different concentrations of AA $(0.07-485 \mu \mathrm{M})$ in the presence of 500.0 DA, $200.0 \mathrm{UA}$, and $200.0 \mu \mathrm{M}$ FA; (B) different concentrations of DA $(0.05-430 \mu \mathrm{M})$ in the presence of $500.0 \mathrm{AA}, 200.0 \mathrm{UA}$, and $200.0 \mu \mathrm{M}$ FA; (C) different concentrations of UA $(0.02-250 \mu \mathrm{M})$ in the presence of $500.0 \mathrm{AA}, 500.0 \mathrm{DA}$, and $200.0 \mu \mathrm{M} \mathrm{FA}$; (D) different concentrations of FA $(0.022-180 \mu \mathrm{M})$ in the presence of 500.0 AA, 500.0 DA, and 200.0 $\mu \mathrm{M}$ UA. DPV experimental conditions: pulse amplitude of $50 \mathrm{mV}$, pulse time of $100 \mathrm{~ms}$, sweep rate of $50 \mathrm{mV} \mathrm{s}^{-1}$; in $0.1 \mathrm{M}$ PBS solution ( $\mathrm{pH} \mathrm{7.0)}$ ).

$200 \mu \mathrm{M} \mathrm{UA}$, and $200 \mu \mathrm{M}$ FA increased with the concentration increase of the DA from 0.05 to $430 \mu \mathrm{M}$ (Fig. 8B). The following linear equations is $\mathrm{I}_{\mathrm{p}, \mathrm{DA}}$ $(\mu \mathrm{A})=-0.815( \pm 0.281)+0.041( \pm 0.001) \mathrm{C}_{\mathrm{DA}}(\mu \mathrm{M})$ $\left(\mathrm{R}^{2}=0.9907\right)$. In the case of UA (Fig. 8C), the oxidation peaks in $0.1 \mathrm{M}$ PBS containing $500 \mu \mathrm{M}$ AA, $500 \mu \mathrm{M}$ DA, and $200 \mu \mathrm{M}$ FA increased gradually from 0.02 to $250 \mu \mathrm{M}$ with an increase in the UA concentration, and $\mathrm{I}_{\mathrm{pa}}$ showed a good linear relationship according to following linear equations: $\mathrm{I}_{\mathrm{p}, \mathrm{UA}}(\mu \mathrm{A})=$ $1.419( \pm 0.195)+0.083( \pm 0.002) \mathrm{C}_{\mathrm{UA}}(\mu \mathrm{M})$ $\left(\mathrm{R}^{2}=0.9965\right)$. Similarly, Fig. 8D shows the DPV curves of FA in $0.1 \mathrm{M} \mathrm{PBS}(\mathrm{pH} 7.0$ ) containing $500 \mu \mathrm{M}$ AA, $500 \mu \mathrm{M}$ DA, and $200 \mu \mathrm{M}$ UA with increasing concentration of FA from 0.022 to $180 \mu \mathrm{M}$. The peak currents of FA increased linearly with an increase in its concentration, according to the linear function: $\mathrm{I}_{\mathrm{p}, \mathrm{FA}}(\mu \mathrm{A})=$ $0.088( \pm 0.228)+0.080( \pm 0.003) \mathrm{C}_{\mathrm{FA}}(\mu \mathrm{M})$
$\left(\mathrm{R}^{2}=0.9907\right)$. Based on the signal-to-noise $(\mathrm{S} / \mathrm{N}=3)$ characteristic, the limit of detection (LOD) was estimated to be $22 \mathrm{nM}, 10 \mathrm{nM}, 5 \mathrm{nM}$, and $6 \mathrm{nM}$ for $\mathrm{AA}$, DA, UA, and FA, respectively.

\subsection{Method validation}

\subsubsection{Linearity and LOD}

The electrochemical responses of the simultaneous detection of AA, DA, UA, and FA in PBS at the $\mathrm{Cu}_{\mathrm{x}} \mathrm{O}-\mathrm{ZnO} / \mathrm{PPy} / \mathrm{RGO} / \mathrm{GCE}$ using DPV were depicted in Fig. 9. The linear ranges and detection limits $(\mathrm{S} / \mathrm{N}=3)$ for $\mathrm{AA}, \mathrm{DA}, \mathrm{UA}$, and FA were presented in Table 1. The results suggest that the simultaneous detection of AA, DA, UA, and FA is feasible at $\mathrm{Cu}_{\mathrm{x}} \mathrm{O}-\mathrm{ZnO} / \mathrm{PPy} / \mathrm{RGO}$ modified GCE.

In Table 2 the comparison with previously developed modified electrodes had reported and it is clear that the proposed electrode exhibits better analytical performance. 

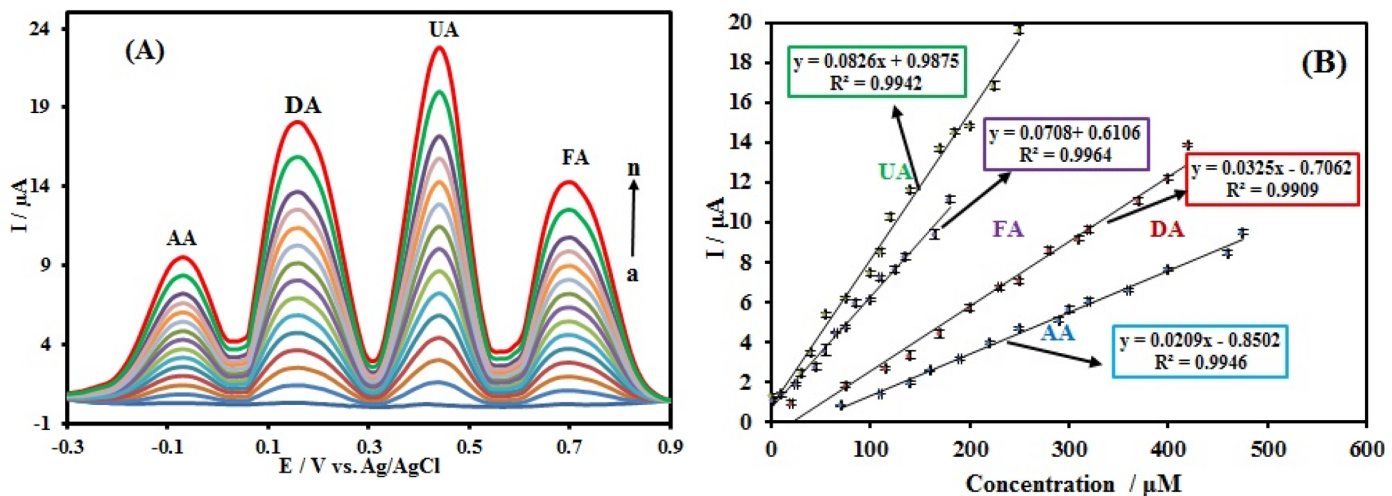

Fig. 9. (A) DPVs for different concentrations of AA, DA, UA, and FA mixtures. As (a) $70+50+5+10$, (b) $110+90+30+20$, (c) $140+110+40+30$, (d) $160+140+55+45$, (e) $190+170+75+55$, (f) $220+200+100+65$, (g) $250+230+110+75$, (h) $290+250+120+85$, (i) $300+280+140+100$, (j) $320+310+170+110$, (k) $360+320+185+125$, (l) $400+370+200+135$, (m) $460+400+225+165$, and (n) $475+420+250+180$, respectively, in which the first value is the concentration of $\mathrm{AA}$ in $\mu \mathrm{M}$, the second value is the concentration of DA in $\mu \mathrm{M}$, the third value is concentration of UA in $\mu \mathrm{M}$ and the fourth value is the concentration of $\mathrm{FA}$ in $\mu \mathrm{M}$. (B) Calibration plots of oxidation peak current versus concentration of each species. DPV experimental conditions: pulse amplitude of $50 \mathrm{mV}$, pulse time of $100 \mathrm{~ms}$, sweep rate of $50 \mathrm{mV} \mathrm{s}^{-1}$; in $0.1 \mathrm{M} \mathrm{PBS}$ solution ( $\mathrm{pH} 7.0$ ). Error bars indicate the standard deviations of three repeated measurements.

Table 1. The regression and quantitation data for simultaneous determination of AA, DA, UA, and FA in PBS at the $\mathrm{Cu}_{\mathrm{x}} \mathrm{O}-$ $\mathrm{ZnO} / \mathrm{PPy} / \mathrm{RGO} / \mathrm{GCE}$ using DPV.

\begin{tabular}{ccccc}
\hline \hline Sample & Linearity range $(\mu \mathrm{M})$ & Slope \pm SD & Intercept \pm SD & LOD $(\mu \mathrm{M})$ \\
\hline AA & $1.5-475$ & $0.021 \pm 0.001$ & $-0.850 \pm 0.131$ & 90 \\
DA & $0.1-420$ & $0.032 \pm 0.001$ & $-0.706 \pm 0.286$ & 48 \\
UA & $0.1-250$ & $0.083 \pm 0.002$ & $0.987 \pm 0.271$ & 28 \\
FA & $1-180$ & $0.071 \pm 0.002$ & $0.611 \pm 0.162$ & 30 \\
\hline
\end{tabular}

Table 2. Comparison for the simultaneous determinations of of AA, DA, UA, and FA at different modified electrodes

\begin{tabular}{|c|c|c|c|c|c|}
\hline Electrode & Technique & Species & $\begin{array}{l}\text { Linear range } \\
\qquad(\mu \mathrm{M})\end{array}$ & $\begin{array}{l}\text { Detection limit } \\
(\mu \mathrm{M})\end{array}$ & Ref. \\
\hline \multirow[t]{2}{*}{${ }^{\mathrm{a}} \mathrm{Ni}$ NPs@Poly1,5-DAN/GCE } & SWV & AA & $100-500$ & 0.01 & [20] \\
\hline & & DA & $100-500$ & 0.011 & \\
\hline \multirow[t]{4}{*}{ b'AuNCs/AGR/MWCNT/GCE } & DPV & AA & $10-150$ & 0.27 & [22] \\
\hline & & DA & $1-210$ & 0.08 & \\
\hline & & UA & $5-100$ & 0.1 & \\
\hline & & FA & $10-170$ & 0.09 & \\
\hline \multirow[t]{3}{*}{$\mathrm{Mn}-\mathrm{SnO}_{2} / \mathrm{GCE}$} & DPV & $\mathrm{AA}$ & $1-900$ & 0.056 & [51] \\
\hline & & UA & $1-860$ & 0.036 & \\
\hline & & FA & $0.5-900$ & 0.079 & \\
\hline \multirow[t]{3}{*}{ c3DGH-Fc/GCE } & DPV & $\mathrm{AA}$ & $20-450$ & 0.183 & [52] \\
\hline & & DA & $10-180$ & 0.042 & \\
\hline & & UA & $8-400$ & 0.067 & \\
\hline \multirow[t]{4}{*}{$\mathrm{Cu}_{\mathrm{x}} \mathrm{O}-\mathrm{ZnO} / \mathrm{PPy} / \mathrm{RGO} / \mathrm{GCE}$} & DPV & $\mathrm{AA}$ & $0.07-485$ & 0.022 & This work \\
\hline & & DA & $0.05-430$ & 0.010 & \\
\hline & & UA & $0.02-250$ & 0.005 & \\
\hline & & FA & $0.022-180$ & 0.006 & \\
\hline
\end{tabular}

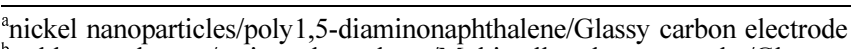

${ }^{b}$ gold nanoclusters/activated graphene/Multiwall carbon nanotube/Glassy carbon electrode

cthree dimensional graphene hydrogel-ferrocene hybrid/ Glassy carbon electrode 
3.6.2 Accuracy and precision

The accuracy was determined using the regression equation that was obtained from the constructed calibration curves at three concentration levels covering low, medium and high range. Good recoveries were achieved and presented in Table 3. For study Intraday precision at three different concentration levels in the same day experiments were done, while for study inter-day precision at different three consecutive days experiments were done. Clearly, the values of RSD in

Table 3. The accuracy, intra-day and inter-day precision for simultaneous determination of AA, DA, UA, and FA in PBS at the $\mathrm{Cu}_{\mathrm{x}} \mathrm{O}-\mathrm{ZnO} / \mathrm{PPy} / \mathrm{RGO} / \mathrm{GCE}$ using DPV.

\begin{tabular}{ccccc}
\hline \hline \multirow{2}{*}{ Sample } & & $\begin{array}{c}\text { Accuracy } \\
(\mathrm{n}=5)\end{array}$ & Intra-day precision $(\mathrm{n}=5)$ & Inter-day precision $(\mathrm{n}=10)$ \\
\cline { 3 - 4 } & Conc. $(\mu \mathrm{M})$ & Percent Recovery \pm SD & Percent Recovery \pm SD & $\begin{array}{c}\text { Percent } \\
\text { Recovery } \pm \text { SD }\end{array}$ \\
\hline \multirow{2}{*}{ AA } & 10 & $99.85 \pm 1.25$ & $100.35 \pm 1.65$ & $101.28 \pm 1.75$ \\
& 200 & $100.52 \pm 1.53$ & $101.32 \pm 1.83$ & $101.47 \pm 2.09$ \\
& 400 & $101.04 \pm 2.03$ & $101.02 \pm 2.16$ & $100.74 \pm 1.79$ \\
DA & 10 & $100.16 \pm 1.48$ & $101.46 \pm 1.27$ & $101.27 \pm 1.34$ \\
& 200 & $101.28 \pm 2.12$ & $100.16 \pm 1.52$ & $100.47 \pm 2.08$ \\
& 400 & $100.29 \pm 1.78$ & $99.85 \pm 2.07$ & $99.67 \pm 1.42$ \\
UA & 10 & $99.79 \pm 2.08$ & $100.79 \pm 1.71$ & $101.51 \pm 1.47$ \\
& 100 & $100.09 \pm 1.17$ & $99.59 \pm 1.19$ & $99.76 \pm 1.58$ \\
& 200 & $100.87 \pm 1.96$ & $101.73 \pm 2.04$ & $100.37 \pm 1.36$ \\
FA & 10 & $99.86 \pm 1.72$ & $100.49 \pm 1.06$ & $100.43 \pm 1.32$ \\
& 100 & $100.59 \pm 2.09$ & $101.19 \pm 1.75$ & $99.29 \pm 1.49$ \\
\hline
\end{tabular}

Table 4. Interferences of some foreign substances for AA $(500 \mu \mathrm{M})$, DA $(500 \mu \mathrm{M})$, UA $(200 \mu \mathrm{M})$, and FA $(200 \mu \mathrm{M})$.

\begin{tabular}{cccccc}
\hline \hline \multirow{2}{*}{ Coexisting species } & Tolerance limit & \multicolumn{3}{c}{ Relative error (\%) } \\
\cline { 3 - 6 }$\left(\mathrm{W}_{\text {ion }} / \mathrm{W}_{\mathrm{AA}, \mathrm{DA}, \mathrm{UA} \text { or FA }}\right)$ & $\mathrm{AA}$ & $\mathrm{DA}$ & $\mathrm{UA}$ & $\mathrm{FA}$ \\
\hline Cysteine & 300 & 2.73 & 1.14 & 0.45 & 1.39 \\
Glucose & 400 & 0.45 & 0.79 & 1.34 & 2.79 \\
$\mathrm{CO}_{3}^{2-}$ & 300 & 1.75 & 0.59 & 1.63 & 2.18 \\
$\mathrm{NO}_{3}^{-}$ & 300 & 1.08 & 1.19 & 1.58 & 1.89 \\
$\mathrm{SCN}^{-}$ & 300 & 1.25 & 1.72 & 0.97 & 1.74 \\
$\mathrm{Cl}^{-}$ & 300 & 0.91 & 2.56 & 1.78 & 2.45 \\
$\mathrm{SO}_{4}^{2-}$ & 300 & 2.37 & 1.59 & 0.67 & 1.09 \\
$\mathrm{Ca}^{2+}$ & 200 & 1.82 & 1.36 & 1.25 & 2.09 \\
$\mathrm{Zn}^{2+}$ & 180 & 1.82 & 2.84 & 0.36 & 1.05 \\
$\mathrm{Cu}^{2+}$ & 100 & 1.36 & 2.10 & 0.40 & 2.94 \\
$\mathrm{Fe}^{3+}$ & 120 & 0.82 & 1.99 & 0.58 & 1.39 \\
$\mathrm{Mg}^{2+}$ & 180 & 2.73 & 2.73 & 1.07 & 3.49 \\
$\mathrm{Na}^{+}$ & 100 & 1.20 & 2.01 & 0.52 & 1.35 \\
$\mathrm{~K}^{+}$ & 120 & 1.03 & 1.05 & 0.53 & 0.85 \\
\hline
\end{tabular}


Table 3 could indicate that, the proposed method was highly precise.

\subsection{Effect of interferences on the behaviors of AA,}

\section{DA, UA, and FA}

Under optimal experimental conditions, the potential influence of some interference was also investigated to evaluate the anti-interferential ability of the modified electrode for the determination of AA, DA, UA, and FA. The results are shown in Table 4. Most common usual interference being derived from any of the cysteine (Cys), glucose (Glu), $\mathrm{Na}^{+}, \mathrm{K}^{+}, \mathrm{Mg}^{2+}$, $\mathrm{Fe}^{3+}, \mathrm{Cu}^{2+}, \mathrm{Zn}^{2+}, \mathrm{Ca}^{2+}, \mathrm{SO}_{4}{ }^{2-}, \mathrm{Cl}^{-}, \mathrm{SCN}^{-}, \mathrm{NO}_{3}{ }^{-}$, and $\mathrm{CO}_{3}{ }^{2-}$. Among these compounds, the interference from any of AA, DA, UA, and FA are very important because their oxidation peak potential are close to

Table 5. Determination of AA, DA, UA, and FA in human serum with $\mathrm{Cu}_{\mathrm{x}} \mathrm{O}-\mathrm{ZnO} / \mathrm{PPy} / \mathrm{RGO} / \mathrm{GCE}$

\begin{tabular}{|c|c|c|c|c|c|}
\hline Sample & Analyte & Added $(\mu \mathrm{M})$ & Found $^{\mathrm{a}}(\mu \mathrm{M})$ & R.S.D. (\%) & Recovery (\%) \\
\hline & & 0 & 20 & 1.09 & - \\
\hline & & 15 & 35.24 & 2.15 & 100.69 \\
\hline \multirow[t]{3}{*}{ Serum $^{\mathrm{a}}$} & AA & 30 & 50.85 & 1.29 & 101.70 \\
\hline & & 45 & 64.89 & 2.36 & 99.83 \\
\hline & & 60 & 81.06 & 1.09 & 101.32 \\
\hline \multirow[t]{6}{*}{ Serum $^{b}$} & $\mathrm{DA}$ & 0 & 5 & 1.23 & - \\
\hline & & 20 & 25.02 & 2.91 & 100.08 \\
\hline & & 40 & 45.12 & 0.68 & 100.26 \\
\hline & & 60 & 64.39 & 1.38 & 99.06 \\
\hline & & 80 & 84.76 & 1.94 & 99.72 \\
\hline & & 100 & 104.31 & 1.36 & 99.33 \\
\hline \multirow[t]{6}{*}{ Serum $^{\mathrm{c}}$} & UA & 0 & 100 & 1.20 & - \\
\hline & & 20 & 120.25 & 3.25 & 100.20 \\
\hline & & 40 & 139.85 & 1.39 & 99.89 \\
\hline & & 60 & 161.56 & 0.76 & 100.97 \\
\hline & & 80 & 179.21 & 2.53 & 99.56 \\
\hline & & 100 & 198.95 & 1.78 & 99.47 \\
\hline \multirow[t]{6}{*}{ Serum $^{\mathrm{d}}$} & FA & 0 & 5 & 1.21 & - \\
\hline & & 10 & 14.86 & 2.88 & 99.07 \\
\hline & & 20 & 25.29 & 1.97 & 101.16 \\
\hline & & 30 & 35.28 & 1.29 & 100.80 \\
\hline & & 40 & 45.56 & 2.32 & 101.24 \\
\hline & & 50 & 55.07 & 0.98 & 100.13 \\
\hline \multirow[t]{4}{*}{ Serum $^{\mathrm{e}}$} & AA & 20 & 20.15 & 0.92 & 100.75 \\
\hline & DA & 20 & 20.26 & 1.52 & 101.3 \\
\hline & UA & 20 & 19.89 & 1.36 & 99.45 \\
\hline & FA & 20 & 20.19 & 1.20 & 100.95 \\
\hline
\end{tabular}

${ }^{a}$ Healthy plasma sample (male, 30 years old).

${ }^{\mathrm{b}}$ Healthy plasma sample (male, 12 years old).

${ }^{c}$ Healthy plasma sample (female, 60 years old).

${ }^{\mathrm{d}}$ Healthy plasma sample (male, 20 years old).

${ }^{\text {e}}$ Healthy plasma sample (female, 35 years old). 
Table 6. Determination of AA, DA, UA, and FA in human urine with $\mathrm{Cu}_{\mathrm{x}} \mathrm{O}-\mathrm{ZnO} / \mathrm{PPy} / \mathrm{RGO} / \mathrm{GCE}$

\begin{tabular}{ccccccc}
\hline \hline Sample & Analyte & Determined & Added $(\mu \mathrm{M})$ & Found $^{\mathrm{a}}(\mu \mathrm{M})$ & R.S.D. $(\%)$ & Recovery $(\%)$ \\
\hline Urine 1 & AA & - & 50 & 49.88 & 1.12 & 99.76 \\
& DA & - & 50 & 50.25 & 0.86 & 100.50 \\
& UA & 100 & 50 & 151.45 & 1.06 & 100.97 \\
\multirow{3}{*}{ Urine 2 } & FA & - & 50 & 49.78 & 1.17 & 99.56 \\
& AA & - & 30 & 30.06 & 1.10 & 100.20 \\
& DA & - & 30 & 30.58 & 0.96 & 101.93 \\
& UA & 50 & 30 & 80.69 & 0.89 & 100.86 \\
& FA & - & 30 & 29.85 & 1.15 & 99.50 \\
\hline
\end{tabular}

each other and they usually are present in real biological samples simultaneously. The data show that interferences are only significant at relatively high concentrations and we can say that this biosensor is free from common interfering species.

\subsection{Real Sample Analysis, Reproducibility, and} Stability

In order to evaluate the applicability of the proposed method, it was used for the determination of AA, DA, UA, and FA in the human plasmatic serum sample. The human plasmatic serum sample was diluted 100 times using 0.1 M PBS (pH 7.0). Differential pulse voltammograms were used for the tests. Concentrations were measured by applying the calibration plot using the standard addition method. The results are shown in Table 5. Recovery studies were also conducted using blood serum and recoveries between $99.83 \%$ to $101.70 \%$ for AA, $99.06 \%$ to $100.26 \%$ for DA, $99.47 \%$ to $100.97 \%$ for UA, and $99.07 \%$ to $101.24 \%$ for FA were obtained.

By using the standard addition method, determinations of AA, DA, UA, and FA in two human urine real samples were performed. To determine the accuracy of the results, the urine samples were diluted 50 times with $0.1 \mathrm{M}$ PBS ( $\mathrm{pH} 7.0$ ) before the measurement to reduce the matrix effect. Then a certain amount of AA, DA, UA, and FA was added to the sample (three times) to evaluate the recoveries. The results are shown in Table 6 . The recovery of the spiked samples ranged between $99.50 \%$ and $101.93 \%$, relative standard deviation $(\mathrm{RSD}, \mathrm{n}=3$ ) ranged within $0.86-1.17 \%$ (Table 6 ). The results indicating the successful application of the $\mathrm{Cu}_{\mathrm{x}} \mathrm{O}-\mathrm{ZnO}$ / $\mathrm{PPy} / \mathrm{RGO}$ nanocomposite for the determination of
AA, DA, UA and FA in real samples.

The reproducibility of $\mathrm{Cu}_{\mathrm{x}} \mathrm{O}-\mathrm{ZnO} / \mathrm{PPy} / \mathrm{RGO} / \mathrm{GCE}$ was evaluated by preparing five parallel electrodes for the determination of $500 \mu \mathrm{M}$ AA, $500 \mu \mathrm{M}$ DA, $200 \mu \mathrm{M}$ UA and $200 \mu \mathrm{M}$ FA. The relative standard deviations of the five electrodes were $3.5 \%, 1.75 \%, 2.5 \%$, and $3.1 \%$ for AA, DA, UA, and FA, respectively.

The stability of the modified electrode was also investigated. After kiping the modified electrode at ambient temperature for 21 days, repeatable sensing performance was achieved for the detection of AA, DA, UA, and FA, suggesting that the sensor has good stability.

\section{Conclusions}

$\mathrm{Cu}_{\mathrm{x}} \mathrm{O}-\mathrm{ZnO} / \mathrm{PPy} / \mathrm{RGO} / \mathrm{GCE}$ was synthesized by electrochemical methods. The $\mathrm{Cu}_{\mathrm{x}} \mathrm{O}-\mathrm{ZnO} / \mathrm{PPy} / \mathrm{RGO} /$ GCE modified electrode is able to simultaneously detect AA, DA, UA, and FA. The method exhibits a wide linear range, high sensitivity, good reproducibility and stability. The human blood serum samples analysis results showed good recoveries. It shows that $\mathrm{Cu}_{\mathrm{x}} \mathrm{O}-\mathrm{ZnO} / \mathrm{PPy} / \mathrm{RGO}$ is a promising electrocatalyst for the detection of AA, DA, UA, and FA.

\section{Acknowledgment}

The authors gratefully acknowledge partial financial support from the Research Council of Alzahra University.

\section{Supporting Information}

Supporting Information is available at https:// doi.org/10.33961/jecst.2019.00472 


\section{References}

[1] W.H. Sebrell, S. Harris (Eds.), The Vitamins, Academic Press, NEW YORK, second ed., 1967.

[2] O. Arrigoni, C.D. Tullio, Ascorbic acid: much more than just an antioxidant, Biochim. Biophys. Acta, 2002, 1569(13), 1-9.

[3] N. Ben-Jonathan, Endocr Rev., 1985, 6(4), 564-589.

[4] E.J. Nestler, Cell, 1994, 79(6), 923-926.

[5] D.M. Jackson, A. Westlind-Danielsson, Pharmacol Ther, 1994, 64(2), 291-370.

[6] R.J. Marttila, Handbook of Parkinson's disease, p. 35. in: W.C. Koller (Ed.), Marcel Dekker, New York, 1987.

[7] V.V.S.E. Dutt, H.A. Mottola, Anal. Chem., 1974, 46(12), 1777-1781.

[8] S.N. Young, Can. J. Physiol. Pharmacol. 1991, 69(7), 893-903.

[9] S.N. Young, Can. J. Physiol. Pharmacol., 1991, 69(7), 893-903.

[10] A. Gottas, A. Ripel, F. Boix, V. Vindenes, J. Mør, E.L. Øiestad, J. Pharmacol. Toxicol. Methods, 2015, 74, 75-79.

[11] X. Wei, Z. Zhang, Z. Wang, Microchem. J., 2019, 145, 55-58.

[12] W. Ga, L. Qi, Z. Liu, S. Majeed, S.A. Kitte, G. Xu, Sens. Actuators B, 2017, 238, 468-472.

[13] H.L. Lee, S.C. Chen, Talanta, 2004, 64(3), 750-757.

[14] J.H. An, D.K. Choi, K.J. Lee, J.W. Choi, Biosens. Bioelectron., 2015, 67, 739-746.

[15] S. Boroumand, M. Arab Chamjangali, Gh. Bagherian, Spectrochim. Acta Part A, 2017, 174, 203-213.

[16] J.H. Ke, H.J. Tseng, C.T. Hsu, J.C. Che n, G. Muthuram an, J.M. Zen, Sens. Actuators B, 2008, 130(2), 614-619.

[17] A. Babaei, A.R. Taheri, Sens. Actuators B, 2013, 176, 543-551.

[18] M. Hasanzadeh, N. Shadjoub, E. Omidinia, Methods, 2013, 219(1), 52-60.

[19] A. Doménech, H. García, M.T. Doménech-Carbó, M.S. Galletero, Anal. Chem., 2002, 74(3), 562-569.

[20] A.A. Hathoot, U.S. Yousef, A.S. Shatla, M. AbdelAzzem, Electrochim. Acta, 2012, 85, 531-537.

[21] Kh. Ghanbari, N. Hajheidari, J. Polym. Res., 2015, 22(8), 152.

[22] A.A. Abdelwahab, Y.B. Shim, Sens. Actuators B, 2015, 221, 659-665.

[23] K.S. Novoselov, A.K. Geim, S.V. Morozov, D. Jiang, Y. Zhang, S.V. Dubonos, I.V. Grigorieva, A.A. Firsov, Science 2004, 306(5696), 666-669.

[24] M. Arvand, T.M. Gholizadeh, Colloids Surf. B 2013, 103, 84-93.

[25] R. Rezaei, M.M. Foroughi, H. Beitollahi, R. Alizadeh, Russ. J. Electrochem., 2018, 54(11), 860-866.

[26] Kh. Ghanbari, S. Bonyadi, New J. Chem., 2018, 42(11), 8512-8523.

[27] S. Stankovich, D.A. Dikin, G.H.B. Dommett, Nature, 2006, 442(7100), 282-286

[28] C. Tseng, Y. Chou, C. Liu, Y. Liu, M. Ger, Y. Shu, Mater.
Res. Bull., 2012, 47(1), 96-100.

[29] S. Luo, F. Su, C. Liu, J. Li, R. Liu, Y. Xiao, Y. Li, X. Liu, Q. Cai, Talanta, 2011, 86, 157-163.

[30] C. Sun, G. Maduraiveeran, P. Dutta, Sens. Actuators B, 2013, 186, 117-125.

[31] F. Shao, M.W.G Hoffmann, J.D. Prades, R. Zamani, J. Arbiol, J.R. Morante, E. Varechkina, M. Rumyantseva, A. Gaskov, I. Giebelhaus, T. Fischer, S. Mathur, F. Hernández-Ramírez, Sen. Actuators B, 2013, 181, 130135.

[32] D. Bekermann, A. Gasparotto, D. Barreca, C. Maccato, E. Comini, C. Sada, G. Sberveglieri, G.Devi, R.A. Fischer, ACS Appl. Mater. Interfaces, 2012, 4(2), 928-934.

[33] J. Huang, Y. Dai, C. Gu, Y. Sun, J. Liu, J. Alloys Compd., 2013, 575, 115-122.

[34] A. Alqudami, S. Annapoorni, P. Sen, R.S. Rawat, Synth Met., 2007, 157(1), 53-59.

[35] Kh. Ghanbari, M. Moloudi, Anal. Biochem., 2016, 512, 91-102.

[36] W.S.H. Jr, R.E. Offeman, J. Am. Chem. Soc., 1958, 80(6), 1339-1339.

[37] Kh. Ghanbari, N. Hajheidari, Anal. Biochem., 2015, 473, 53-62.

[38] I.C.O, Harmonization, Topic Q2 (R1) Validation of Analytical Procedures: Text and Methodology, 2005.

[39] A. Pruna, Q. Shao, M. Kamruzzaman, Y.Y. Li, J.A. Zapien, D. Pullini, D. Busquets Mataix, A. Ruotolo, Appl. Surf. Sci., 2017, 392, 801-809.

[40] T. Terasako, T. Yamanaka, S. Yura, M. Yagi, S. Shirakata, Thin Solid Films, 2010, 519(5), 1546-1551.

[41] W. Wang, Y. Tu, L. Wang, Y. Liang, H. Shi, Appl. Surf. Sci., 2013, 264, 399-403.

[42] A.J. Bard, L.R. Faulkner, Electrochemical Methods: Fundamentals and Applications, 2nded.Wiley, USA, 2000.

[43] Q. Huang, H. Zhang, S. Hu, F. Li, W. Weng, J. Chen, Q. Wang, Y. He, W. Zhang, X. Bao, Biosens. Bioelectron., 2014, 52, 277-280.

[44] E. Laviron, J. Electroanal. Chem. Interfacial Electrochem. 1979, 101(1), 19-28.

[45] R. Nicholson, I. Shain, Anal. Chem., 1964, 36(4), 706-723.

[46] A. Bard, L. Faulkner, Electrochemical methods, 2nd ed., John Wiley \& Sons, New York, 2001.

[47] E.L. Ciolkowski, K.M. Maness, P.S. Cahlil, R.M. Wightman, Anal. Chem., 1994, 66(21), 3611-3617.

[48] C. Díaz, C. Garcí a, P. Iturriaga-Vásqu ez, M.J. Agui rre, J.P. M uena, R. Cont reras, R. Ormazábal- Toledo, M. Isaacs, Electrochim. Acta, 2013, 111, 846-854.

[49] C. Amatore, J.M. Saveant, J. Electroanal. Chem., 1978, 86(1), 227-232.

[50] H. R. Zare, M.R. Shishehbore, D. Nematollahi, Electrochim. Acta, 2011, 58, 654-661.

[51] N. Lavanya, E. Fazio, F. Neri, A. Bonavita, S.G Leonardi, G. Neri, C. Sekar, J. Electroanal. Chem., 2016, 770, 23-32.

[52] Q. Zhu, J. Ba o, D. H uo, M. Y ang, H. Wu, C. Hou, Y. Zhao, X. Luo, H. Fa, J. Electroanal. Chem., 2017, 799, 459-467. 